\title{
Article \\ Chemical Constituents of Hedyotis diffusa and Their Anti-Inflammatory Bioactivities
}

\author{
Hsin-Yi Hung ${ }^{1,+}\left(\mathbb{D}\right.$, Kun-Ching Cheng ${ }^{2,+}{ }^{,}$Ping-Chung Kuo ${ }^{1}{ }^{\circledR}$, I-Tsen Chen ${ }^{3}$, Yue-Chiun Li ${ }^{1}$, \\ Tsong-Long Hwang ${ }^{4,5,6} \odot$, Sio-Hong Lam ${ }^{1, *}$ and Tian-Shung $\mathrm{Wu}^{1, *}$
}

1 School of Pharmacy, College of Medicine, National Cheng Kung University, Tainan 70101, Taiwan; z10308005@email.ncku.edu.tw (H.-Y.H.); z10502016@ncku.edu.tw (P.-C.K.); 10803048@gs.ncku.edu.tw (Y.-C.L.)

2 Taiwan Sugar Research Institute, Tainan 70176, Taiwan; a64128@taisugar.com.tw

3 Department of Chemistry, National Cheng Kung University, Tainan 70101, Taiwan; 136021212@gs.ncku.edu.tw

4 Graduate Institute of Natural Products, College of Medicine, Chang Gung University, Taoyuan 33305, Taiwan; ht1@mail.cgu.edu.tw

5 Research Center for Chinese Herbal Medicine, Research Center for Food and Cosmetic Safety, Graduate Institute of Health Industry Technology, College of Human Ecology, Chang Gung University of Science and Technology, Taoyuan 33305, Taiwan

6 Department of Anesthesiology, Chang Gung Memorial Hospital, Taoyuan 33305, Taiwan

* Correspondence: shlam@mail.ncku.edu.tw (S.-H.L.); tswu@mail.ncku.edu.tw (T.-S.W.); Tel.: +886-6-2353535 (ext. 6807) (S.-H.L.); +886-6-2757575 (ext. 65333) (T.-S.W.)

+ These authors contributed equally to this work.

check for updates

Citation: Hung, H.-Y.; Cheng, K.-C.; Kuo, P.-C.; Chen, I.-T.; Li, Y.-C.; Hwang, T.-L.; Lam, S.-H.; Wu, T.-S. Chemical Constituents of Hedyotis diffusa and Their Anti-Inflammatory Bioactivities. Antioxidants 2022, 11, 335. https://doi.org/10.3390/ antiox11020335

Academic Editor: Alessandra Napolitano

Received: 3 January 2022

Accepted: 1 February 2022

Published: 9 February 2022

Publisher's Note: MDPI stays neutral with regard to jurisdictional claims in published maps and institutional affiliations.

Copyright: (c) 2022 by the authors. Licensee MDPI, Basel, Switzerland. This article is an open access article distributed under the terms and conditions of the Creative Commons Attribution (CC BY) license (https:/ / creativecommons.org/licenses/by/ $4.0 /)$.

\begin{abstract}
Seven new anthraquinones with rare 2-isopropyldihydrofuran (1-3) and 2,2-dimethylpyrano (4-7) moieties together with thirty-four known compounds were isolated from the extracts of whole Hedyotis diffusa plants. Their structures were elucidated and established by various spectroscopic and spectrometric analytical methods. Among these isolates, selected compounds were examined for their anti-inflammatory activity. The results showed that rare substituted anthraquinones displayed potent inhibitory activity with $\mathrm{IC}_{50}$ values ranging from $0.15 \pm 0.01$ to $5.52 \pm 1.59 \mu \mathrm{M}$ on the $N$-formyl-methionyl-leucyl-phenylalanine/cytochalasin B (fMLP/CB)-induced superoxide anion generation and elastase release cellular models. Meanwhile, the proposed drug target of the active anthraquinone was studied by computer modeling. The binding affinity between the anti-inflammatory anthraquinone and elastase was evaluated by molecular docking. These results provided the scientific insight into the medicinal values of Hedyotis diffusa and vision of development as lead compounds.
\end{abstract}

Keywords: Hedyotis diffusa; superoxide anion; elastase release; human neutrophils; anthraquinone

\section{Introduction}

Hedyotis diffusa Willd. (Rubiaceae) is a plant commonly used as folk medicine and distributed in southern provinces of China [1]. The herb of $H$. diffusa has the effects of clearing heat and detoxifying, relieving pain and dispelling masses, diuresis, and dehumidification [2]. It is mainly used for treating lung heat, asthma and cough, gastroenteritis, appendicitis, urinary system infection, throat swelling and pain, intestinal carbuncle sore, dysentery, malignant tumors, etc. [2]. According to the literature, more than 180 compounds have been characterized from $H$. diffusa, including iridoids, flavonoids, anthraquinones, phenolics, volatile oils, and polysaccharides [3-8]. Previous studies indicated that $H$. diffusa exhibits various pharmacological activities, including antioxidant, antiangiogenic, antiinflammatory, hepatoprotective, apoptosis, and anticancer activities [3,8-16]. Ursolic and oleanolic acid isolated from $H$. diffusa display specific anti-tumor activity against colorectal cancer COLO205, liver cancer Hep 3B, and lung cancer H460 cell lines [17]. Moreover, methylanthraquinones from $H$. diffusa induced cell apoptosis by changing Fas and Fas Ligand (Fas/FasL) and activating caspase -8 in THP-1 cells of human leukemia [18] 
or increased $\mathrm{Ca}^{2+}$ concentration in human breast cancer cells through phosphorylation of c-Jun N-terminal kinase (JNK) protein kinase and activation of calpain to promote cell apoptosis [19]. 2-Hydroxy-3-methylanthraquinone can also enhance the apoptosis of leukemia cells U937 by modulating mitogen-activated protein kinase (MAPK), activating $\mathrm{p}$-p38MAPK and reducing phosphorylated extracellular signal-regulated kinase (p-ERK1/2), with $\mathrm{IC}_{50}$ of $66 \mu \mathrm{M}$ [20]. Iridoid glycoside $E-6-O-p$-methoxycinnamoyl scandoside methyl ester inhibited human neutrophil elastase with an $\mathrm{IC}_{50}$ of $18 \mu \mathrm{M}$ [21]. Total flavonoids of $H$. diffusa improved the colonic mucosal damage, increased superoxide dismutase (SOD) activity in colon tissue, and reduced the myeloperoxidase, malondialdehyde (MDA), and nitric oxide (NO) activities in ulcerative colitis model rats [22]. Treatment with a homogeneous polysaccharide $(25,100$, and $200 \mu \mathrm{g} / \mathrm{mL})$ from $H$. diffusa resulted in growth inhibitory effect on A549 cells by inducing apoptosis [23].

Neutrophils, the largest type of macrophages, account for 50 to $60 \%$ of the total circulating white blood cells and play a major role in inflammatory response [24]. In addition to phagocytosis and enzyme secretion against pathogenic bacteria, neutrophils also secrete some peroxides, such as superoxide anion. Moreover, neutrophils are involved in other immune responses during inflammation, such as the production of elastase. The main function of elastase is to hydrolyze elastin, which can decompose injured cells and invading pathogenic bacteria in the infected area, and to complete the entire protection of host cells and tissues through apoptosis [25,26]. Therefore, inhibition of elastase secretion and superoxide anion formation can effectively reduce cell inflammation. A human neutrophil cell model activated by $\mathrm{N}$-formyl-methionyl-leucyl-phenylalanine/cytochalasin $\mathrm{B}(\mathrm{fMLP} / \mathrm{CB})$ to inhibit superoxide anion generation and elastase release was used as a screening platform for anti-inflammatory activity in our previous study $[27,28]$. In the preliminary screening of a series of Chinese herbal medicines with heat-clearing and detoxification potentials, the $H$. diffusa ethanol extracts displayed 71.71 and $38.26 \%$ inhibitory activities at $10 \mu \mathrm{g} / \mathrm{mL}$ in $\mathrm{fMLP} / \mathrm{CB}$-induced superoxide anion generation and elastase release assay, respectively. Moreover, the ethanol extract of $H$. diffusa also has an inhibitory effect on hepatitis $\mathrm{C}$ virus and Dengue virus, with $\mathrm{IC}_{50}$ and $\mathrm{EC}_{50}$ values against hepatitis $\mathrm{C}$ virus of 131.1 and $49.5 \mu \mathrm{g} / \mathrm{mL}$, respectively (unpublished data). At a sample concentration of $25 \mu \mathrm{g} / \mathrm{mL}$, the methanol extract of $H$. diffusa reduced the RNA expression of Dengue virus by $30.0 \pm 8.1 \%$ (unpublished data). According to these experimental screening data, the chemical components of the ethanol extract of $H$. diffusa were thoroughly separated and identified. The anti-inflammatory activity of the major chemical components and their molecular docking with elastase were also investigated. This research is expected to provide an important reference for the development of anti-inflammatory lead compounds, healthy foods, and cosmetic products.

\section{Materials and Methods}

\subsection{General Experimental Procedures}

A Jasco P-2000 digital polarimeter (Jasco, Tokyo, Japan) with $589 \mathrm{~nm}$ filter was used to measure the optical rotations of purified compounds. The ultraviolet (UV) spectra were determined on a Hitachi U-0080-D UV/Vis spectrometer (Hitachi, Tokyo, Japan) with a $1.0 \mathrm{~cm}$ length cell. The infrared (IR) spectra were recorded on a PerkinElmer FT-IF spectrum RX I (PerkinElmer, Waltham, MA, USA) using KBr pellets. Circular dichroism (CD) spectra were determined on the Jasco J-720 spectropolarimeter (Jasco, Tokyo, Japan). One-dimensional and two-dimensional NMR spectra were recorded on the Bruker Avance III 400 or Avance III HD 700 NMR spectrometer (Bruker, Billerica, MA, USA) using $\mathrm{CDCl}_{3}$, acetone- $d_{6}$, or methanol- $d_{4}$ as solvent with tetramethylsilane as an internal standard. HRESI mass spectra were acquired from the Bruker APEX II mass spectrometer. Preparative high performance liquid chromatography (HPLC) was carried out on a Shimadzu LC-8A instrument (Shimadzu, Kyoto, Japan) equipped with UV-VIS detector (Shimadzu SPD-10A, Kyoto, Japan) and a Cosmosil 5C18-MS-II column $(20 \times 250$ mm, Nacalai Tesque Kyoto, Japan). Column chromatography was performed on Geduran Si 60 (40-63 $\mu \mathrm{m}$, Merck, 
Darmstadt, Germany). Thin-layer chromatography (TLC) was carried out using precoated Kieselgel $60 \mathrm{~F}_{254}$ plates (Merck), in which compounds were visualized by UV light or spraying with anisaldehyde solution followed by heating at $120^{\circ} \mathrm{C}$.

\subsection{Plant Material}

Dried whole herbs of $H$. diffusa were purchased from Chuang Song Zong Pharmaceutical Co. Ltd., Pingtung, Taiwan, in September 2013. The plant materials were authenticated by Prof. Chang-Sheng Kuoh, Department of Life Science, National Cheng Kung University (NCKU), Tainan, Taiwan. A voucher specimen (TSWu 2015-001-001) was deposited at School of Pharmacy, College of Medicine, National Cheng Kung University, Tainan, Taiwan.

\subsection{Extraction and Isolation}

The whole herbs of $H$. diffusa $(5.2 \mathrm{~kg})$ were refluxed with $95 \%$ ethanol $(3 \times 10 \mathrm{~L})$ to give ethanol extract $(370 \mathrm{~g})$ after evaporation under reduced pressure. This crude extract was suspended in water and partitioned successively with ethyl acetate (EtOAc) to afford the EtOAc soluble fraction (110 g), water soluble layer (220 g), and precipitate (40 g).

The EtOAc-soluble fraction ( $110 \mathrm{~g}$ ) was separated by silica gel column chromatography $\left(\mathrm{SiO}_{2} \mathrm{CC}\right)$ eluted with a gradient of hexane-EtOAc $(9: 1$ to $0: 1)$ to give fifteen fractions (EtOAc-fractions, E-Fr. 1-15). E-Fr. 3 was isolated by $\mathrm{SiO}_{2} \mathrm{CC}$ eluted with hexane-diisopropyl ether (30:1) to produce several subfractions, and recrystallization of subfractions E-Fr. 3-4 and 3-5 afforded 9 (1.9 mg), $11(28.9 \mathrm{mg}), \mathbf{1 8}(8.2 \mathrm{mg}), \mathbf{2 5}(4.2 \mathrm{mg})$, $4(9.1 \mathrm{mg})$, and $35(2.2 \mathrm{mg})$. Compound $1(2.4 \mathrm{mg})$ was further collected from E-Fr. 3-6 by preparative $\mathrm{HPLC}$ eluted with $\mathrm{MeOH}-\mathrm{H}_{2} \mathrm{O}$ (9:1, flow rate $\left.=10 \mathrm{~mL} / \mathrm{min}\right)$. E-Fr. 4 was also chromatographed on $\mathrm{SiO}_{2} \mathrm{CC}$ eluted with hexane-acetone (30:1), and further TLC purification or recrystallization of the resulting subfraction E-Fr. 4-3 afforded $23(11.8 \mathrm{mg})$. Compounds 21 (17.8 mg), 19 (18.2 mg), $24(1.0 \mathrm{mg}), \mathbf{5}(2.4 \mathrm{mg})$, and $\mathbf{7}(0.5 \mathrm{mg})$ were collected after separation by silica gel CC eluted with hexane-chloroform (1:2), preparative TLC, and recrystallization of subfraction E-Fr. 4-5. Subfraction E-Fr. 4-8 was isolated by $\mathrm{SiO}_{2} \mathrm{CC}$, eluted with hexane-di-isopropyl ether (1:1) to give $\mathbf{1 6}(1.4 \mathrm{mg}), \mathbf{1 4}(2.3 \mathrm{mg}), \mathbf{2 0}(3.5 \mathrm{mg})$, and 26 (7.1 mg). Subfraction E-Fr. 4-9 was also isolated by the similar procedures described as Fr. $4-8$, and finally $\mathbf{1 0}(0.6 \mathrm{mg}), \mathbf{1 1}(19.3 \mathrm{mg})$, and $\mathbf{1 7}(1.2 \mathrm{mg})$ were collected. Recrystallization of E-Fr. 6, 7, and 8 produced mixture of 39 and $40(424.2 \mathrm{mg}), \mathbf{1 2}(566.4 \mathrm{mg})$, and mixture of 37 and $38(120.6 \mathrm{mg})$, respectively. Fraction E-Fr. 11 was subjected to $\mathrm{SiO}_{2} \mathrm{CC}$ eluted with diisopropyl ether-hexane (30:1) to afford several subfractions. Of these, selected subfractions were further isolated by $\mathrm{SiO}_{2} \mathrm{CC}$ and subsequent preparative TLC to yield $15(17.2 \mathrm{mg})$, $6(0.6 \mathrm{mg})$, and $41(14.8 \mathrm{mg})$. Compounds $2(3.3 \mathrm{mg})$ and $3(1.1 \mathrm{mg})$ were obtained from Fraction E-Fr. 12 by $\mathrm{SiO}_{2} \mathrm{CC}$ eluted with chloroform-acetone (30:1). Fraction E-Fr. 13 was subjected to $\mathrm{SiO}_{2} \mathrm{CC}$ eluted with chloroform-acetone (10:1) to produce $22(4.6 \mathrm{mg})$ and $8(2.7 \mathrm{mg})$. Fraction E-Fr. 14 was isolated by $\mathrm{SiO}_{2}$ CC eluted with chloroform-MeOH (20:1) and a step gradient of $\mathrm{MeOH}$ to afford several subfractions. Compounds $31(174.2 \mathrm{mg})$ and $32(174.3 \mathrm{mg})$ were collected from subfraction E-Fr. 14-4 after preparative HPLC eluted with $\mathrm{MeOH}-\mathrm{H}_{2} \mathrm{O}$ (1:1, flow rate $\left.=10 \mathrm{~mL} / \mathrm{min}\right)$. The same procedure was undertaken to obtain $29(30.8 \mathrm{mg})$ and $30(30.4 \mathrm{mg})$ from subfraction E-Fr. 14-6. Subfraction E-Fr. 14-5 was separated by a preparative HPLC eluted with $\mathrm{MeOH}-\mathrm{H}_{2} \mathrm{O}(4: 6$, flow rate $=10 \mathrm{~mL} / \mathrm{min})$ to collect $33(27.3 \mathrm{mg})$ and $34(27.3 \mathrm{mg})$. The water-soluble layer $(220 \mathrm{~g})$ was separated by Diaion $\mathrm{HP}-20 \mathrm{CC}$, eluted with a gradient of $\mathrm{MeOH}-\mathrm{H}_{2} \mathrm{O}(0: 1$ to 1:0) to give eleven fractions (Water-fractions, W-Fr. 1-11). W-Fr. 7 was separated by $\mathrm{SiO}_{2} \mathrm{CC}$ eluted with chloroform-MeOH (8:1) to afford 36 (2.8 mg). Compounds $27(14.2 \mathrm{mg})$ and 28 (70.1 mg) were isolated from W-Fr. 11 by $\mathrm{SiO}_{2} \mathrm{CC}$ eluted with chloroform-MeOH (5:1) (summarized in Scheme 1). 


\section{H. diffisa ethanol extract $(370 \mathrm{~g})$}

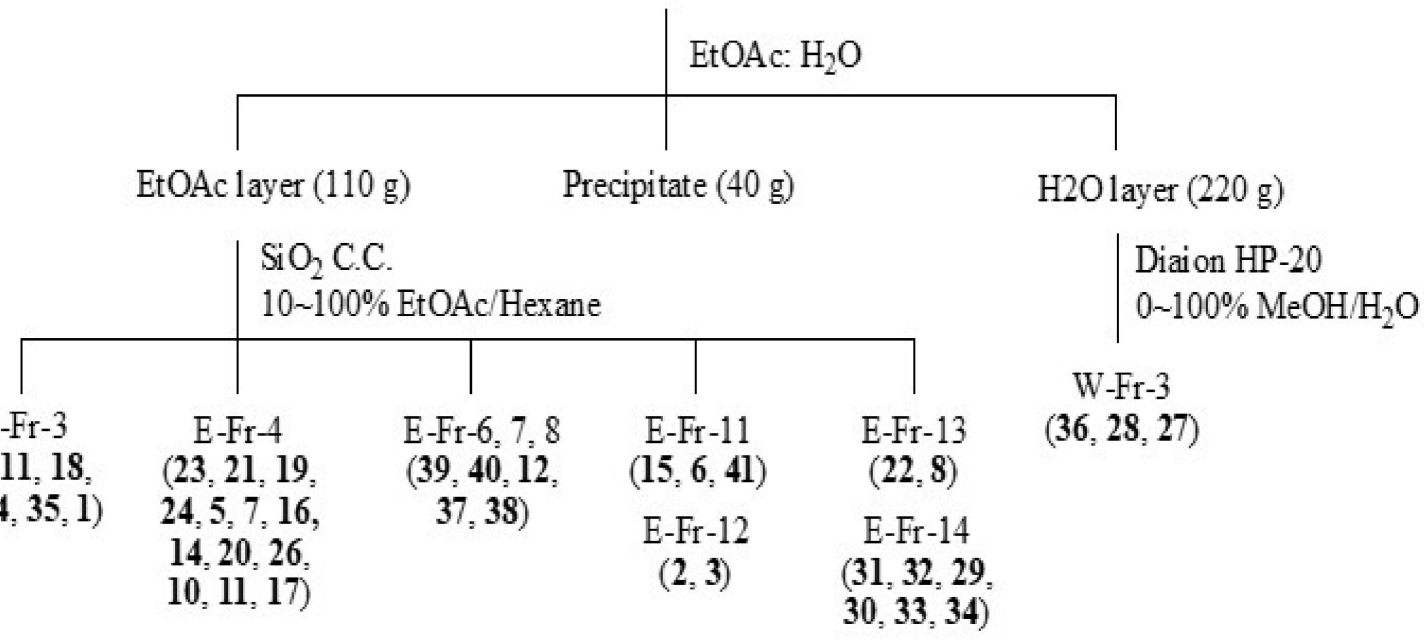

Scheme 1. The extraction and isolation flow chart of $H$. diffusa.

2.4. Spectral and Physical Data of $\mathbf{1}-\mathbf{7}$

2.4.1. Diffusaquinone A (1)

Yellow powder; $[\alpha]_{D}{ }^{25}+2.4\left(c\right.$ 0.1, MeOH); UV (MeOH) $\lambda_{\max } 375,274,245,211 \mathrm{~nm}$; IR $(\mathrm{KBr}) v_{\max } 2927,2861,1668,1585,1447,1293 \mathrm{~cm}^{-1}$; ECD $\left(\mathrm{CHCl}_{3}\right) \mathrm{nm}(\mathrm{Mol} . \mathrm{CD}) 321(+0.01)$ 298 (+1.58), 267 (+0.19), 255 (+0.42), 240 (-1.19), $227(+1.01), 213(-0.89) ;{ }^{1} \mathrm{H} \mathrm{NMR}(400 \mathrm{MHz}$, $\left.\mathrm{CDCl}_{3}\right)$, see Table $1 ;{ }^{13} \mathrm{C} \mathrm{NMR}\left(100 \mathrm{MHz}, \mathrm{CDCl}_{3}\right)$, see Table 2; ESI-MS m/z $305[\mathrm{M}+\mathrm{H}]^{+}$; HR-ESI-MS m/z 305.1174 [M+H] $]^{+}$(calcd. for $\mathrm{C}_{20} \mathrm{H}_{17} \mathrm{O}_{3}, 305.1172$ ).

Table 1. The ${ }^{1} \mathrm{H}$ NMR spectral data of compounds $1-7$.

\begin{tabular}{|c|c|c|c|c|c|c|c|}
\hline & $1^{a}$ & $2^{b}$ & $3^{c}$ & $4^{a}$ & $5^{a}$ & $6^{d}$ & $7^{a}$ \\
\hline Position & \multicolumn{7}{|c|}{$\delta_{H}(p p m$, multi, $J$ in $\mathrm{Hz})$} \\
\hline 1 & $8.05(\mathrm{~s})$ & $7.60(\mathrm{~s})$ & $7.45(\mathrm{~s})$ & $8.07(\mathrm{~s})$ & $7.78(\mathrm{~s})$ & $7.47(\mathrm{~s})$ & $7.80(\mathrm{~s})$ \\
\hline 5 & $\begin{array}{c}8.22(\mathrm{dd}, J=8.8 \\
2.4 \mathrm{~Hz})\end{array}$ & $\begin{array}{c}8.08(\mathrm{~d}, J= \\
8.0 \mathrm{~Hz})\end{array}$ & 7.96 (brs) & $8.21(\mathrm{~m})$ & $\begin{array}{c}8.10(\mathrm{~d}, J= \\
8.0 \mathrm{~Hz})\end{array}$ & $\begin{array}{c}8.03(\mathrm{~d}, J= \\
7.0 \mathrm{~Hz})\end{array}$ & $\begin{array}{l}7.64(\mathrm{~d}, J= \\
7.6 \mathrm{~Hz})\end{array}$ \\
\hline 6 & $7.76(\mathrm{~m})$ & $\begin{array}{c}7.65(\mathrm{dd}, J= \\
8.0,1.6 \mathrm{~Hz})\end{array}$ & - & $7.73(\mathrm{~m})$ & $\begin{array}{c}7.55(\mathrm{dd}, J= \\
8.0,1.2 \mathrm{~Hz})\end{array}$ & $\begin{array}{c}7.55(\mathrm{brd}, J= \\
7.0 \mathrm{~Hz})\end{array}$ & $\begin{array}{l}7.48(\mathrm{~d}, J= \\
7.6 \mathrm{~Hz})\end{array}$ \\
\hline 7 & $7.76(\mathrm{~m})$ & - & $\begin{array}{l}7.58(\mathrm{brd}, J= \\
8.0 \mathrm{~Hz})\end{array}$ & $7.73(\mathrm{~m})$ & & & \\
\hline 8 & $\begin{array}{c}8.28(\mathrm{dd}, J=8.8 \\
2.4 \mathrm{~Hz})\end{array}$ & $\begin{array}{c}7.98(\mathrm{~d}, J= \\
1.6 \mathrm{~Hz})\end{array}$ & $\begin{array}{c}8.09(\mathrm{~d}, J= \\
8.0 \mathrm{~Hz})\end{array}$ & $8.21(\mathrm{~m})$ & $\begin{array}{c}8.01(\mathrm{~d}, J= \\
1.2 \mathrm{~Hz})\end{array}$ & 7.94 (brs) & \\
\hline 11 & $2.37(\mathrm{~s})$ & $2.51(\mathrm{~s})$ & $2.49(\mathrm{~s})$ & $2.32(\mathrm{~s})$ & $2.50(\mathrm{~s})$ & $2.43(\mathrm{~s})$ & $2.35(\mathrm{~s})$ \\
\hline $1^{\prime}$ & $\begin{array}{c}3.93(\mathrm{dd}, J= \\
18.0,10.0 \mathrm{~Hz}) \alpha \\
3.54(\mathrm{dd}, J= \\
18.0,8.0 \mathrm{~Hz}) \beta\end{array}$ & $\begin{array}{c}3.70(\mathrm{~d}, J= \\
8.0 \mathrm{~Hz})\end{array}$ & $\begin{array}{c}5.77(\mathrm{~d}, J=4.0 \\
\mathrm{Hz})\end{array}$ & $\begin{array}{c}7.87(\mathrm{~d}, J= \\
10.4 \mathrm{~Hz})\end{array}$ & $\begin{array}{c}7.93(\mathrm{~d}, J= \\
10.8 \mathrm{~Hz})\end{array}$ & $7.50(\mathrm{~s})$ & $\begin{array}{c}7.92(\mathrm{~d}, J= \\
10.4 \mathrm{~Hz})\end{array}$ \\
\hline $2^{\prime}$ & $\begin{array}{c}5.39(\mathrm{br} \mathrm{t}, J= \\
8.0 \mathrm{~Hz})\end{array}$ & $\begin{array}{l}4.89(\mathrm{t}, J= \\
8.0 \mathrm{~Hz})\end{array}$ & $\begin{array}{c}4.45(\mathrm{~d}, J= \\
4.0 \mathrm{~Hz})\end{array}$ & $\begin{array}{c}5.94(\mathrm{~d}, J= \\
10.4 \mathrm{~Hz})\end{array}$ & $\begin{array}{c}5.93(\mathrm{~d}, J= \\
10.8 \mathrm{~Hz})\end{array}$ & & $\begin{array}{l}5.94(\mathrm{~d}, J= \\
10.4 \mathrm{~Hz})\end{array}$ \\
\hline $4^{\prime}$ & $\begin{array}{l}5.13(\mathrm{~s}) \alpha \\
4.96(\mathrm{~s}) \beta\end{array}$ & $1.32(\mathrm{~s})$ & $1.33(\mathrm{~s})$ & $1.50(\mathrm{~s})$ & $1.53(\mathrm{~s})$ & $1.60(\mathrm{~s})$ & $1.54(\mathrm{~s})$ \\
\hline $\begin{array}{c}5^{\prime} \\
\mathrm{OH}-8\end{array}$ & $1.80(\mathrm{~s})$ & $1.27(\mathrm{~s})$ & $1.29(\mathrm{~s})$ & $1.50(\mathrm{~s})$ & $1.53(\mathrm{~s})$ & $1.60(\mathrm{~s})$ & $\begin{array}{c}1.54(\mathrm{~s}) \\
12.93(\mathrm{~s})\end{array}$ \\
\hline
\end{tabular}

${ }^{1} \mathrm{H}$ NMR data $(\delta)$ were measured in ${ }^{\text {a }} \mathrm{CDCl}_{3}$ at $400 \mathrm{MHz} ;{ }^{\text {b }}$ acetone- $\mathrm{d}_{6}$ at $400 \mathrm{MHz} ;{ }^{\mathrm{c}}$ methanol- $\mathrm{d}_{4}$ at $400 \mathrm{MHz}$; ${ }^{\mathrm{d}}$ methanol- $\mathrm{d}_{4}$ at $700 \mathrm{MHz}$. 
Table 2. The ${ }^{13} \mathrm{C}$ NMR spectral data of compounds $1-7$.

\begin{tabular}{|c|c|c|c|c|c|c|c|}
\hline & $1^{a}$ & $2^{b}$ & $3^{c}$ & $4^{a}$ & $5^{a}$ & $6^{d}$ & $7^{a}$ \\
\hline Position & & & & $\delta_{C}(p p m$ & & & \\
\hline 1 & 130.7 & 114.4 & 117.0 & 130.2 & 113.7 & 110.7 & 113.4 \\
\hline 2 & 125.8 & 145.7 & 144.4 & 132.5 & 149.0 & 151.5 & 149.0 \\
\hline 3 & 164.3 & 153.5 & 155.3 & 157.1 & 144.8 & 148.8 & 145.2 \\
\hline 4 & 128.1 & 131.4 & 130.8 & 120.7 & 121.8 & 132.0 & 122.1 \\
\hline $4 a$ & 128.6 & 128.9 & 129.9 & 126.6 & 121.8 & 120.1 & 122.1 \\
\hline 5 & 126.7 & 126.6 & 126.5 & 127.0 & 127.2 & 127.9 & 118.9 \\
\hline 6 & 133.5 & 134.3 & 144.4 & 133.6 & 134.6 & 136.0 & 136.9 \\
\hline 7 & 133.9 & 144.6 & 134.0 & 133.4 & 144.3 & 146.0 & 133.7 \\
\hline 8 & 127.1 & 126.7 & 126.5 & 126.5 & 126.8 & 128.3 & 160.4 \\
\hline $8 a$ & 133.8 & 133.6 & 132.0 & 127.2 & 132.6 & 134.8 & 114.8 \\
\hline 9 & 182.3 & 181.7 & 183.4 & 182.9 & 182.9 & 185.2 & 188.2 \\
\hline $9 a$ & 127.2 & 123.4 & 120.0 & 132.9 & 129.7 & 134.0 & 129.2 \\
\hline 10 & 184.5 & 182.6 & 183.3 & 185.7 & 184.6 & 184.2 & 184.1 \\
\hline $10 \mathrm{a}$ & 127.2 & 131.8 & 133.5 & 134.9 & 132.7 & 133.5 & 132.8 \\
\hline 11 & 15.8 & 20.8 & 20.4 & 16.5 & 21.8 & 21.9 & 16.0 \\
\hline $1^{\prime}$ & 36.1 & 32.2 & 73.3 & 120.9 & 120.9 & 104.1 & 120.8 \\
\hline $2^{\prime}$ & 87.7 & 92.0 & 96.2 & 133.8 & 133.5 & 170.0 & 133.7 \\
\hline $3^{\prime}$ & 143.4 & 70.7 & 70.7 & 76.6 & 78.0 & 70.2 & 78.2 \\
\hline $4^{\prime}$ & 112.4 & 24.7 & 23.6 & 28.0 & 27.9 & 29.2 & 28.0 \\
\hline $5^{\prime}$ & 17.1 & 25.0 & 24.1 & 28.0 & 27.9 & 29.2 & 28.0 \\
\hline
\end{tabular}

${ }^{13} \mathrm{C}$ NMR data $(\delta)$ were measured in ${ }^{\mathrm{a}} \mathrm{CDCl}_{3}$ at $100 \mathrm{MHz} ;{ }^{\mathrm{b}}$ acetone- $\mathrm{d}_{6}$ at $100 \mathrm{MHz} ;{ }^{\mathrm{c}}$ methanol- $\mathrm{d}_{4}$ at $100 \mathrm{MHz}$; $\mathrm{d}$ methanol-d $\mathrm{d}_{4}$ at $175 \mathrm{MHz}$.

\subsubsection{Diffusaquinone B (2)}

Yellow powder; $[\alpha]_{D}^{25}-4.6$ (c 0.1, MeOH); UV (MeOH) $\lambda_{\max } 413,293,248,210 \mathrm{~nm}$; IR (KBr) $v_{\max } 3389,2927,2857,1664,1574,1344,1292 \mathrm{~cm}^{-1}$; ECD (MeOH) nm (Mol. CD) 350 (+0.17), 342 (0.00), 306 (+1.36), 280 (-0.25), 244 (+0.24), 208 (-1.07), 197 (+0.03); ${ }^{1} \mathrm{H}$ NMR $\left(400 \mathrm{MHz}\right.$, acetone- $\left.\mathrm{d}_{6}\right)$, see Table $1 ;{ }^{13} \mathrm{C}$ NMR $\left(100 \mathrm{MHz}\right.$, acetone- $\left.\mathrm{d}_{6}\right)$, see Table 2; ESI-MS $m / z 339[\mathrm{M}+\mathrm{H}]^{+}$; HR-ESI-MS m/z $361.1045[\mathrm{M}+\mathrm{Na}]^{+}$(calcd. for $\mathrm{C}_{20} \mathrm{H}_{18} \mathrm{O}_{5} \mathrm{Na}, 361.1046$ ).

\subsubsection{Diffusaquinone C (3)}

Yellow powder; $[\alpha]_{D}^{25}+119.5(c 0.1, \mathrm{MeOH}) ; \mathrm{UV}(\mathrm{MeOH}) \lambda_{\max } 400,291,249,211 \mathrm{~nm}$; IR (KBr) $v_{\max } 3445,2927,1662,1574,1348,1292 \mathrm{~cm}^{-1}$; ECD (MeOH) nm (Mol. CD) 368 $(-0.32), 351(+0.25), 342(+0.01), 303(+1.08), 281(-0.28), 229(+0.33), 209(-0.95) ;{ }^{1} \mathrm{H}$ NMR $\left(400 \mathrm{MHz}\right.$, methanol- $\left.\mathrm{d}_{4}\right)$, see Table $1 ;{ }^{13} \mathrm{C}$ NMR $\left(100 \mathrm{MHz}\right.$, methanol- $\left.\mathrm{d}_{4}\right)$, see Table 2; ESI-MS $m / z 353$ [M-H] ${ }^{-}$; HR-ESI-MS m/z 353.1033 [M-H] ${ }^{-}$(calcd. for $\mathrm{C}_{20} \mathrm{H}_{17} \mathrm{O}_{6}, 353.1031$ ).

\subsubsection{Diffusaquinone D (4)}

Yellow powder; UV (MeOH) $\lambda_{\max } 289,276,248,208 \mathrm{~nm}$; IR (KBr) $v_{\max } 2926,1727$, $1665,1578,1327,1304 \mathrm{~cm}^{-1} ;{ }^{1} \mathrm{H}$ NMR $\left(400 \mathrm{MHz}, \mathrm{CDCl}_{3}\right)$, see Table $1 ;{ }^{13} \mathrm{C}$ NMR $(100 \mathrm{MHz}$, $\mathrm{CDCl}_{3}$ ), see Table 2; ESI-MS m/z $305[\mathrm{M}+\mathrm{H}]^{+}$; HR-ESI-MS m/z $305.1170[\mathrm{M}+\mathrm{H}]^{+}$(calcd. for $\left.\mathrm{C}_{20} \mathrm{H}_{17} \mathrm{O}_{3}, 305.1172\right)$.

\subsubsection{Diffusaquinone E (5)}

Yellow powder; UV (MeOH) $\lambda_{\max }$ 290, 273, 253, $208 \mathrm{~nm}$; IR (KBr) $v_{\max } 3377,2978$, 2930, 1665, 1571, $1333 \mathrm{~cm}^{-1} ;{ }^{1} \mathrm{H}$ NMR $\left(400 \mathrm{MHz}, \mathrm{CDCl}_{3}\right)$, see Table $1 ;{ }^{13} \mathrm{C}$ NMR $(100 \mathrm{MHz}$, $\mathrm{CDCl}_{3}$ ), see Table 2; ESI-MS $m / z 321[\mathrm{M}+\mathrm{H}]^{+}$; HR-ESI-MS $m / z 321.1124[\mathrm{M}+\mathrm{H}]^{+}$(calcd. for $\mathrm{C}_{20} \mathrm{H}_{17} \mathrm{O}_{4}, 321.1121$ ).

\subsubsection{Diffusaquinone F (6)}

Yellow powder; UV (MeOH) $\lambda_{\max } 408,287,259,214 \mathrm{~nm}$; IR (KBr) $v_{\max } 3300,2925$, 2855, 1700, 1663, 1560, 1361, 1332, $1303 \mathrm{~cm}^{-1} ;{ }^{1} \mathrm{H}$ NMR (700 MHz, methanol-d $\mathrm{d}_{4}$ ), see Table 1 ; 
${ }^{13} \mathrm{C}$ NMR (175 MHz, methanol-d ${ }_{4}$ ), see Table 2; ESI-MS m/z 359 [M+Na] ${ }^{+}$; HR-ESI-MS m/z $359.0891[\mathrm{M}+\mathrm{Na}]^{+}$(calcd. for $\mathrm{C}_{20} \mathrm{H}_{16} \mathrm{O}_{5} \mathrm{Na}, 359.0890$ ).

\subsubsection{Diffusaquinone G (7)}

Yellow powder; UV (MeOH) $\lambda_{\max }$ 418, 294, 256, $223 \mathrm{~nm}$; IR (KBr) $v_{\max } 3393,2931$, 1642, 1566, 1353, 1320, 1253, $1119 \mathrm{~cm}^{-1} ;{ }^{1} \mathrm{H}$ NMR $\left(400 \mathrm{MHz}, \mathrm{CDCl}_{3}\right)$, see Table $1 ;{ }^{13} \mathrm{C}$ NMR $\left(100 \mathrm{MHz}, \mathrm{CDCl}_{3}\right)$, see Table 2; ESI-MS m/z $337[\mathrm{M}+\mathrm{H}]^{+}$; HR-ESI-MS m/z $337.1068[\mathrm{M}+\mathrm{H}]^{+}$ (calcd. for $\mathrm{C}_{20} \mathrm{H}_{17} \mathrm{O}_{5}, 337.1071$ ).

\subsection{Anti-Inflammatory Bioactivity Examination}

\subsubsection{Human Neutrophil Preparation}

Neutrophils were isolated using the standard method of dextran sedimentation prior to centrifugation on a Ficoll Hypaque gradient and hypotonic lysis of erythrocytes. Blood was drawn from healthy human donors (20-30 years old) by venipuncture into heparin-coated vacutainer tubes; the protocol was approved by the review committee of Chang Gung Memorial Hospital (IRB plan number: 103-7405A3 and 201902217A3). Purified neutrophils were pelleted and then re-suspended in $1 \mathrm{mM}$ calcium $\left(\mathrm{Ca}^{2+}\right)$-contained Hank's balanced salt solution (HBSS) buffer at pH 7.4 for anti-inflammatory assays [27].

\subsubsection{Superoxide Anion Generation Measurement}

The assay of the generation of superoxide anion was based on the SOD-inhibitable reduction of ferricytochrome c. Neutrophils $\left(6 \times 10^{5}\right.$ cells $\left./ \mathrm{mL}\right)$ were equilibrated in the presence of $0.6 \mathrm{mg} / \mathrm{mL}$ ferricytochrome $c$ at $37^{\circ} \mathrm{C}$ for $2 \mathrm{~min}$ and incubated with each test compound or vehicle ( $0.1 \%$ DMSO, negative control) for $5 \mathrm{~min}$. Cells were incubated with cytochalasin B (CB, $1 \mu \mathrm{g} / \mathrm{mL})$ for $3 \mathrm{~min}$. Neutrophils were then activated by $\mathrm{N}$-formylL-methionyl-L-leucyl-L-phenylalanine (fMLP, $100 \mathrm{nM}$ ). The changes in the absorbance of ferricytochrome $c$ reduction at $550 \mathrm{~nm}$ were continuously monitored in a double-beam, sixcell positioner spectrophotometer (Hitachi U-3010, Tokyo, Japan) with constant stirring. A phosphatidylinositol 3-kinase (PIK3) inhibitor, LY294002, was used as a positive control [27].

\subsubsection{Elastase Release Assay}

Degranulation of azurophilic granules was determined by elastase release as described previously. Elastase substrate used in experiments was MeO-Suc-Ala-Ala-ProVal-p-nitroanilide. After supplementation with MeO-Suc-Ala-Ala-Pro-Val-p-nitroanilide $(100 \mu \mathrm{M})$, neutrophils $\left(6 \times 10^{5} / \mathrm{mL}\right)$ were equilibrated at $37^{\circ} \mathrm{C}$ for $2 \mathrm{~min}$ and incubated with test compounds or vehicle ( $0.1 \% \mathrm{DMSO}$, negative control) for $5 \mathrm{~min}$. Cells were activated by $100 \mathrm{nM}$ fMLP and $0.5 \mu \mathrm{g} / \mathrm{mL} \mathrm{CB}$, and absorbance changes at $405 \mathrm{~nm}$ were continuously monitored to measure release of elastase. LY294002 was used as a positive control [27].

\subsubsection{Statistical Analysis}

The results are expressed as the mean \pm standard error of the mean (SEM). 50\% Inhibition concentration $\left(\mathrm{IC}_{50}\right)$ was calculated using a computer (PHARM/PCS v4.2). Student's $t$ test was used for statistical comparison among each group. Values of $p$ less than 0.05 were considered statistically significant.

\subsection{Molecular Docking Study}

An AutoDock Vina software (v.1_1_2) was used for the in silico evaluation [29]. The crystal structure of the Human neutrophil elastase was downloaded from the Protein Databank (PDB ID: 1H1B). The 3D structures of ligands were constructed in the Chem3D program. AutodockTools (ADT v1.5.6) carries out the hydrogen supplementation, Gasteiger charge measurement of protein atoms, and selection of ligand flexible torsions. Center at $18.6,11.8$, and $22.8(\mathrm{x}, \mathrm{y}, \mathrm{z})$ of grid box was determined. The binding affinity energy was provided as docking scores and shown in $\mathrm{kcal} / \mathrm{mol}$. Biovia Discovery Studio client 2020 analyzed the visualization of the best docking interactions [30]. 


\section{Results and Discussion}

The ethanol extract was fractionated into several layers by liquid-liquid partition. Further chromatography purification resulted in the characterization of twenty-six anthraquinones (1-26), eight iridoids glycosides (27-34), two phenolics (35-36), two triterpenoids (37-38), two steroids (39-40), and one amide (41). Among these isolates, seven anthraquinones, diffusaquinone A-H (1-7), were reported for the first time from natural sources, and their structures were established on the basis of $1 \mathrm{D}$ and 2D NMR and mass spectrometric analyses. All ${ }^{1} \mathrm{H}$ and ${ }^{13} \mathrm{C}$ NMR results are summarized in Tables 1 and 2.

\subsection{Structural Elucidation of Compounds 1-7}

Compound 1 (Figure 1) was isolated as an optically active yellow powder. Molecular formula of $\mathrm{C}_{20} \mathrm{H}_{16} \mathrm{O}_{3}$ was established on the basis of HR-ESI-MS $\left(\mathrm{m} / z\right.$ 305.1174 for $[\mathrm{M}+\mathrm{H}]^{+}$, calcd. for $\mathrm{C}_{20} \mathrm{H}_{17} \mathrm{O}_{3}, 305.1172$, Figure S1). The absorbance maxima at 245 and $275 \mathrm{~nm}$ in its UV spectrum were the typical feature of an anthraquinone-type compound [31]. The IR spectrum showed absorption bands at 1668, 1585, and $1447 \mathrm{~cm}^{-1}$ that indicated the presence of conjugated carbonyl groups and aromatic ring functionalities. The ${ }^{1} \mathrm{H} \mathrm{NMR}$ spectrum of 1 (Table 1, Figure S2) exhibited signals for five aryl protons, composed of an ABCD system $(\delta 8.28(1 \mathrm{H}, \mathrm{dd}, J=8.8,2.4 \mathrm{~Hz}, \mathrm{H}-8), 8.22(1 \mathrm{H}, \mathrm{dd}, J=8.8,2.4 \mathrm{~Hz}, \mathrm{H}-5)$, $7.76(2 \mathrm{H}, \mathrm{m}, \mathrm{H}-6 / \mathrm{H}-7))$, and a singlet at $\delta 8.05(1 \mathrm{H}, \mathrm{s}, \mathrm{H}-1)$. The ${ }^{13} \mathrm{C}$ NMR spectra (Table 2, Figure S3) revealed twelve carbon signals corresponding to two aryl groups, composed of a di-substituted aryl $(\delta 127.2$ (s, C-10a), 133.8 (s, C-8a), 127.1 (d, C-8), $133.9(\mathrm{~d}, \mathrm{C}-7), 133.5(\mathrm{~d}, \mathrm{C}-6)$ and $126.7(\mathrm{~d}, \mathrm{C}-5))$ and a penta-substituted aryl $(\delta 127.2(\mathrm{~s}$, C-9a), 128.6 (s, C-4a), 128.1 (s, C-4), 164.3 (s, C-3), 125.8 (s, C-2), and 130.7 (d, C-1)). These signals together with two carbonyl carbons $(\delta 182.3(\mathrm{C}-9)$ and $184.5(\mathrm{C}-10))$ and one methyl carbon ( $\delta 15.8, \mathrm{Me}-11)$ suggested the presence of a 9, 10-anthraquinone basic skeleton. The key heteronuclear multiple bond correlation (HMBC, Figure S4) ${ }^{2} \mathrm{~J}$ - and ${ }^{3} \mathrm{~J}-$ correlations of $\mathrm{H}-1(\delta 8.05)$ to $\mathrm{C}-2 / \mathrm{C}-3 / \mathrm{C}-9 / \mathrm{C}-11, \mathrm{H}-5(\delta 8.22)$ to $\mathrm{C}-10, \mathrm{H}-8(\delta 8.28)$ to $\mathrm{C}-9, \mathrm{Me}-11$ ( $\delta 2.37)$ to $\mathrm{C}-2 / \mathrm{C}-3$ determined the location of methyl group at $\mathrm{C}-2$ therefore supported the 2-methyl-9, 10-anthraquinone skeleton. The NOESY correlations (Figure S5) between Me-11 to $\mathrm{H}-1$ was also confirmed this connection. The remaining ${ }^{1} \mathrm{H}$ NMR and COSY correlations (Figure S6) signals included those for an -OCH-CH- system at $\delta 5.39\left(1 \mathrm{H}, \mathrm{t}, J=8.0 \mathrm{~Hz}, \mathrm{H}-2^{\prime}\right), 3.93\left(1 \mathrm{H}, \mathrm{dd}, J=18.0,10.0 \mathrm{~Hz}, \mathrm{H}-1^{\prime} \alpha\right)$, and $3.54(1 \mathrm{H}, \mathrm{dd}$, $\left.J=18.0,8.0 \mathrm{~Hz}, \mathrm{H}-1^{\prime} \beta\right)$, together with one methyl signals $\left(\delta 1.80\left(3 \mathrm{H}, \mathrm{s}, \mathrm{Me}-5^{\prime}\right)\right)$ and two terminal olefinic protons $\left(\delta 5.13\left(1 \mathrm{H}, \mathrm{br} \mathrm{s}, \mathrm{H}-4^{\prime} \alpha\right), 4.96\left(1 \mathrm{H}, \mathrm{br} \mathrm{s}, \mathrm{H}-4^{\prime} \beta\right)\right)$. In addition, five corresponding carbon signals in the ${ }^{13} \mathrm{C}$ and HSQC NMR spectra (Figure S7), including two olefinic carbons $\left(\delta 143.4\left(\mathrm{~s}, \mathrm{C}-3^{\prime}\right)\right.$ and $\left.112.4\left(\mathrm{t}, \mathrm{C}-4^{\prime}\right)\right)$, one oxygenated methine $(\delta 87.7$, $\left.\mathrm{d}, \mathrm{C}-2^{\prime}\right)$, one methylene $\left(\delta 36.1, \mathrm{t}, \mathrm{C}-1^{\prime}\right)$, and one methyl $\left(\delta 17.1, \mathrm{q}, \mathrm{C}-5^{\prime}\right)$ indicated the appearance of the isopentenyl dihydrofuranyl moiety in 1 . The observed ${ }^{2} J$ - and ${ }^{3} J$ - HMBC correlations (Figure 2 and Figure S4) of the isopentenyl moiety from $\mathrm{H}-1^{\prime} \alpha(1 \mathrm{H}, \delta 3.93)$ to $\mathrm{C}-3$, from $\mathrm{H}-1^{\prime} \beta(1 \mathrm{H}, \delta 3.54)$ to $\mathrm{C}-3^{\prime}$, and from $\mathrm{H}-4^{\prime} \beta\left(\delta 4.96,1 \mathrm{H}\right.$, s) to $\mathrm{C}-3^{\prime} / \mathrm{C}-5^{\prime}$ established that this moiety was fused at $C-3$ and $C-4$ of the anthraquinone. The absolute configuration at $C-2^{\prime}$ of $\mathbf{1}$ was determined by the CD spectrum (Figure S8), which showed a positive Cotton effect at $298 \mathrm{~nm}$. This result is consistent with the positive value of $R$-dihydrocolumbianetin reported in the literature [32], which therefore determines the configuration of $C-2^{\prime}$ as $R$. Based on these above data of $\mathbf{1}$, its chemical structure was established as shown in Figure 1 and named trivially as diffusaquinone A.

Compounds 2 and 3 (Figure 1) were isolated as yellow solids and exhibited similar UV, IR, and ${ }^{1} \mathrm{H}$ - and ${ }^{13} \mathrm{C}$-NMR spectra (Tables 1 and 2) as those of diffusaquinone A (1). The molecular formula of 2 was determined as $\mathrm{C}_{20} \mathrm{H}_{18} \mathrm{O}_{5}$ by HR-ESI-MS data $(\mathrm{m} / \mathrm{z} 361.1045$ for $[\mathrm{M}+\mathrm{Na}]^{+}$, Figure S9). In the aromatic region of ${ }^{1} \mathrm{H}-\mathrm{NMR}$ and COSY spectra of 2 (Table 1, Figures S10 and S11), an ABX system at $\delta 8.08(1 \mathrm{H}, \mathrm{d}, J=8.0 \mathrm{~Hz}, \mathrm{H}-5), \delta 7.98(1 \mathrm{H}, \mathrm{d}, J=1.6 \mathrm{~Hz}$, $\mathrm{H}-8)$, and $7.65(1 \mathrm{H}, \mathrm{dd}, J=8.0,1.6 \mathrm{~Hz}, \mathrm{H}-6)$ suggested the presence of a tri-substituted aryl group in 2. The ${ }^{13} \mathrm{C}-$, DEPT and HSQC NMR spectra of 2 (Figures S12 and S13) revealed that the isopentenyl dihydrofuranyl moiety in $\mathbf{1}$ was replaced by five carbon signals at $\delta 92.0(\mathrm{~d}$, 
$\left.\mathrm{C}-2^{\prime}\right), 70.7\left(\mathrm{~s}, \mathrm{C}-3^{\prime}\right), 32.2\left(\mathrm{t}, \mathrm{C}-1^{\prime}\right), 25.0\left(\mathrm{q}, \mathrm{C}-5^{\prime}\right)$, and 24.7( $\left.\mathrm{q}, \mathrm{C}-4^{\prime}\right)$. Two singlet methyls at $\delta 1.27(3 \mathrm{H}, \mathrm{s}, \mathrm{Me}-5)$ and $\delta 1.32\left(3 \mathrm{H}, \mathrm{s}, \mathrm{Me}-4^{\prime}\right)$ belonging to a 2-hydroxy-isopropylfuran moiety were located next to the oxygenated methine $\left(\delta_{\mathrm{H}} 4.89\left(1 \mathrm{H}, \mathrm{t}, J=8.0 \mathrm{~Hz}, \mathrm{H}-2^{\prime}\right)\right.$; $\left.\delta_{\mathrm{C}} 92.0\right)$ evidenced by the HMBC correlations (Figure S14) from $\mathrm{H}-4^{\prime}(\delta 1.32,3 \mathrm{H}, \mathrm{s})$ and $\mathrm{H}-5^{\prime}(\delta 1.27,3 \mathrm{H}, \mathrm{s})$ to $\mathrm{C}-2^{\prime} / \mathrm{C}-3^{\prime}$, and from $\mathrm{H}-1^{\prime}(\delta 3.70,1 \mathrm{H}, \mathrm{d}, J=8.0 \mathrm{~Hz})$ to $\mathrm{C}-3^{\prime}$. Another methyl group $(\delta 2.51, \mathrm{~s}, \mathrm{Me}-11)$ and hydroxyl substituent were located at $\mathrm{C}-7$ $(\delta 144.6, \mathrm{~s})$ and $\mathrm{C}-2(\delta 145.7, \mathrm{~s})$, as confirmed by the HMBC correlations from Me-11 $(\delta$ $2.51,3 \mathrm{H}, \mathrm{s})$ to $\mathrm{C}-6 / \mathrm{C}-7 / \mathrm{C}-8$, and from $\mathrm{H}-1(\delta 7.60,1 \mathrm{H}, \mathrm{s})$ to $\mathrm{C}-3 / \mathrm{C}-9$, respectively. From the NOESY spectrum (Figure S15) of 2 , the NOE correlations between $\mathrm{H}-1^{\prime}$ ( $\delta 5.77$, $1 \mathrm{H}, \mathrm{d}, J=4.0 \mathrm{~Hz}$ ) and $\mathrm{H}-2^{\prime}$, and $\mathrm{Me}-4^{\prime} / \mathrm{Me} 5^{\prime}$ confirmed the relative configuration of $\mathrm{H}-1^{\prime}$ as $\beta$. The CD spectrum (Figure S16) of 2 also displayed a positive Cotton effect at $306 \mathrm{~nm}$, which confirmed the same $R$ configuration at $C-2^{\prime}$ as that of 1 . Subsequently, all the other spectral data analyses confirmed the structure of 2 as 2-hydroxy-3,4-[2' (1-hydroxy-1-methylethyl)-dihydrofurano]-7-methyl-9,10-anthraquinone, as shown in Figure 1, and named diffusaquinone B following the convention. The HR-ESI-MS analytical data (Figure S17) determined the molecular formula of 3 as $\mathrm{C}_{20} \mathrm{H}_{18} \mathrm{O}_{6}$. The ${ }^{1} \mathrm{H}-,{ }^{13} \mathrm{C}-$, COSY and HSQC NMR spectral (Figures S18-S21) characteristics revealed the possibility that 3 possessed one more hydroxyl group than 2 . Based on the ${ }^{2} J$ - and ${ }^{3} J$-HMBC (Figure S22) correlations of $\mathrm{Me}-11(\delta 2.49,3 \mathrm{H}, \mathrm{s})$ to $\mathrm{C}-5 / \mathrm{C}-6 / \mathrm{C}-7$, the methyl group was determined to be attached at $\mathrm{C}-6(\delta 144.4, \mathrm{~s})$ in 3 rather than at $\mathrm{C}-7$ in 2 . The NOESY correlations (Figure S23) between Me-11 to H-5/H-7 was also confirmed this connection. The additional hydroxyl group was substituted at $\mathrm{C}-1^{\prime}(\delta 73.3, \mathrm{~d})$ of the dihydrofuran ring due to the ${ }^{3} J$-HMBC correlations between $\mathrm{H}-1^{\prime}(\delta 5.77,1 \mathrm{H}, \mathrm{d}, J=4.0 \mathrm{~Hz})$ and $\mathrm{C}-3 / \mathrm{C}-3^{\prime}$. The positive Cotton effect at $303 \mathrm{~nm}$ (Figure S24) displayed the same $\beta$-configuration of $\mathrm{H}-1^{\prime}$ as 2 . Therefore, the structure of 3 was concluded as 2 -hydroxy-3,4-[1'-hydroxy-2'-(1hydroxy-1-methylethyl)-dihydrofurano]-6-methyl-9,10-anthraquinone and named as diffusaquinone $\mathrm{C}$.
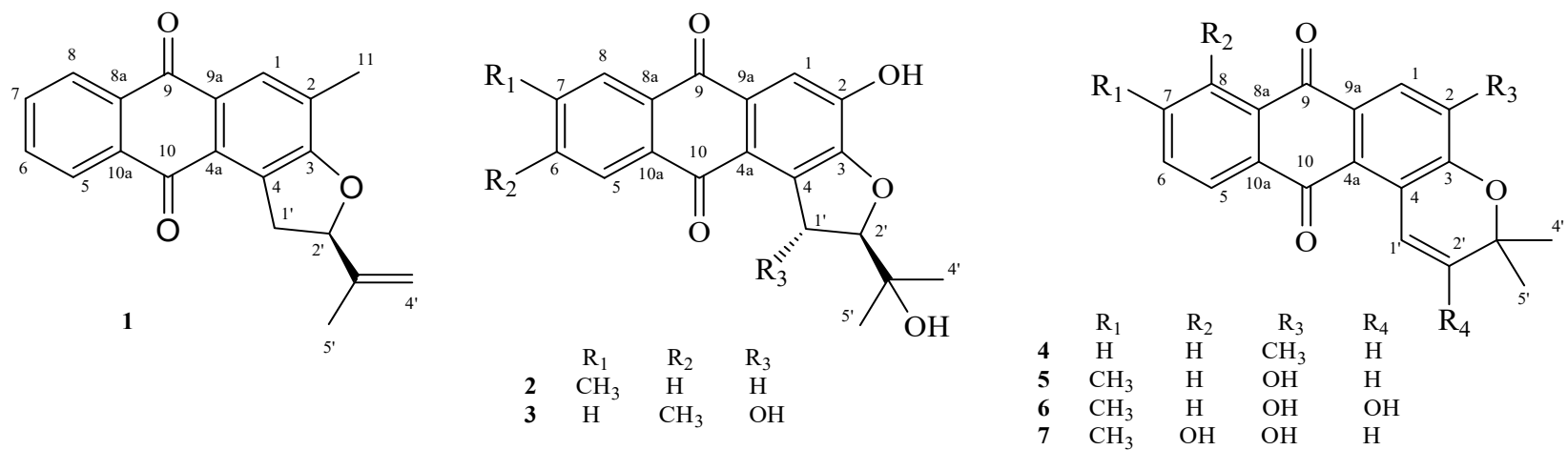

Figure 1. Structures of anthraquinones 1-7 isolated from $H$. diffusa.

Compound 4 (Figure 1), collected as yellow powder, had a molecular formula $\mathrm{C}_{20} \mathrm{H}_{17} \mathrm{O}_{3}$ deduced from HR-ESI-MS spectrum $\left(\mathrm{m} / z 305.1170[\mathrm{M}+\mathrm{H}]^{+}\right.$, calcd. 305.1172, Figure S25). Some of its 1D (Figures S26 and S27) and 2D NMR data (Figures S28-S31) were similar to those of 1 , including an $\mathrm{ABCD}$ system $(\delta 8.21(2 \mathrm{H}, \mathrm{m}, \mathrm{H}-5 / \mathrm{H}-8), 7.76(2 \mathrm{H}, \mathrm{m}, \mathrm{H}-6 / \mathrm{H}-7))$ and a proton singlet at $\delta 8.07(1 \mathrm{H}, \mathrm{s})$, suggesting the presence of 9,10-anthraquinone basic skeleton as that of $\mathbf{1}$ (Tables 1 and 2). The methyl ( $\delta 2.32, \mathrm{~s}, \mathrm{Me}-11)$ was located at $\mathrm{C}-2(\delta$ 132.5 , s), determined by the HMBC correlation (Figure S31) between $\mathrm{H}-1(\delta 8.07,1 \mathrm{H}, \mathrm{s})$ and $\mathrm{C}-11(\delta 16.5, \mathrm{q})$. In addition, the presence of two methyls $\left(\delta 1.50\left(6 \mathrm{H}, \mathrm{s}, \mathrm{Me}-4^{\prime} / 5^{\prime}\right)\right)$, and two cis-coupled olefinic protons $\left(\delta 7.87\left(1 \mathrm{H}, \mathrm{d}, J=10.4 \mathrm{~Hz}, \mathrm{H}-1^{\prime}\right)\right.$ and $5.94(1 \mathrm{H}, \mathrm{d}$, $\left.\left.J=10.4 \mathrm{~Hz}, \mathrm{H}-2^{\prime}\right)\right)$ were observed. Meanwhile, two olefinic carbons $\left(\delta 133.8\left(\mathrm{~d}, \mathrm{C}-2^{\prime}\right), \delta\right.$ $\left.120.9\left(\mathrm{~d}, \mathrm{C}-1^{\prime}\right)\right)$, one oxygenated quaternary carbon $\left(\delta 76.6, \mathrm{~s}, \mathrm{C}-3^{\prime}\right)$, and two methyls $(\delta$ 28.0, $\mathrm{q}, \mathrm{C}-4^{\prime} / \mathrm{C}-5^{\prime}$ ) in the ${ }^{13} \mathrm{C}-\mathrm{NMR}$ spectrum (Figure S27) supported the appearance of 2,2-dimethylpyrano moiety in 4 . In its $\mathrm{HMBC}$ spectrum, ${ }^{2} \mathrm{~J}$ - and ${ }^{3} \mathrm{~J}$-correlations from $\mathrm{H}-1^{\prime}$ 
( $\delta 7.87)$ to $\mathrm{C}-3 / \mathrm{C}^{\prime}$, from $\mathrm{H}-2^{\prime}$ ( $\left.\delta 5.94\right)$ to $\mathrm{C}-3^{\prime} / \mathrm{C}-4^{\prime} / \mathrm{C}-5^{\prime}$, and from $\mathrm{Me}-4^{\prime} / \mathrm{Me}-5^{\prime}$ $(6 \mathrm{H}, \delta 1.50, \mathrm{~s})$ to $\mathrm{C}-2^{\prime}$ indicated that the 2,2-dimethylpyrano ring was fused at $\mathrm{C}-3 / \mathrm{C}-4$, with the oxygen attached at $C-3(\delta 157.1, s)$ in an angular form. All the other spectral data confirmed the structure of 4 as shown in Figure 1, and it was named diffusaquinone D.
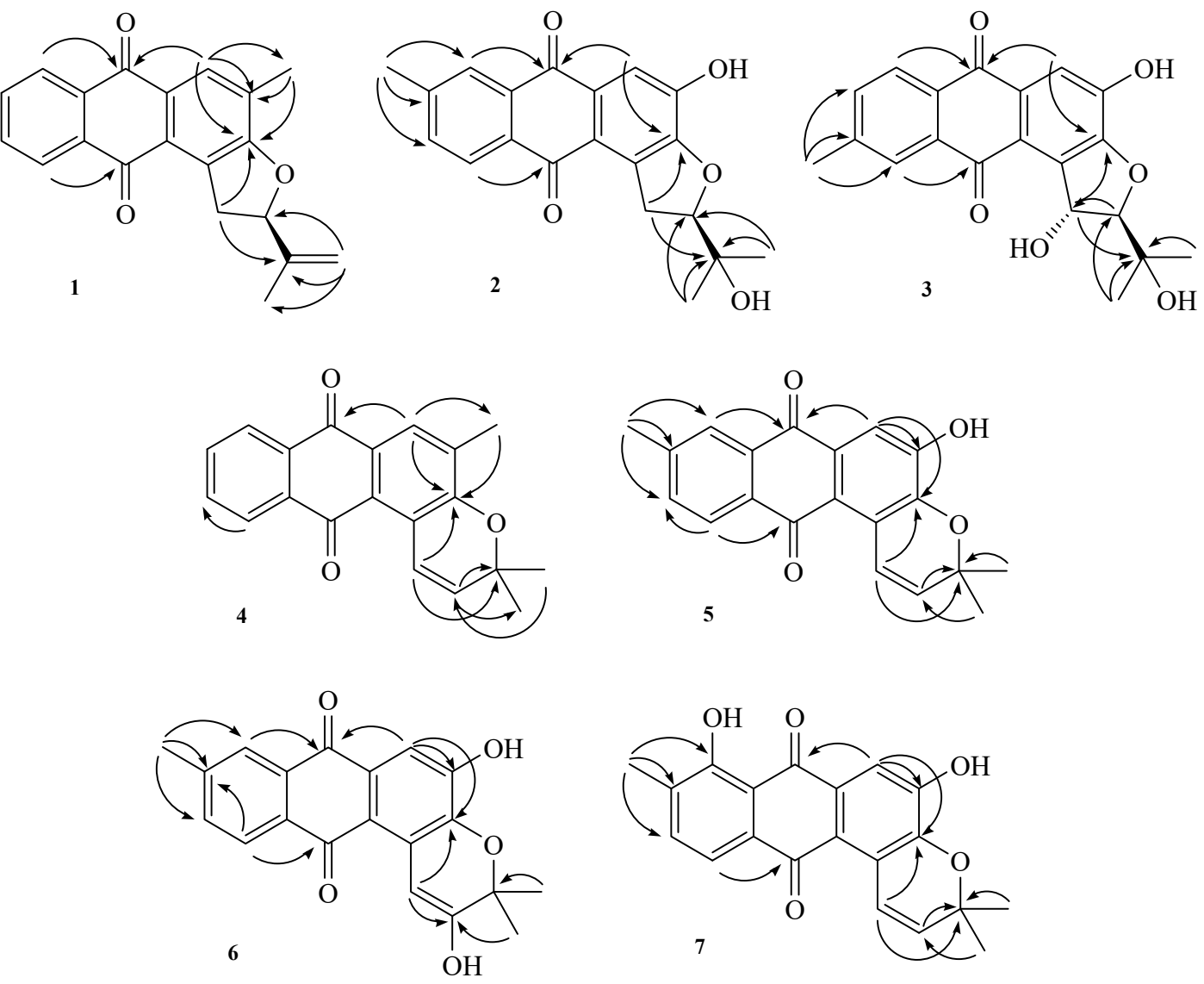

Figure 2. Significant HMBC correlations of anthraquinones 1-7.

Compound 5 (Figure 1) had a molecular formula $\mathrm{C}_{20} \mathrm{H}_{17} \mathrm{O}_{4}$ deduced from HR-ESI-MS analytical data (Figure S32), which had one more oxygen than 4 , revealed the possibility that 5 possessed one more hydroxyl group than 4 . The ${ }^{1} \mathrm{H}$ and COSY NMR spectral data (Figures S33 and S34) in the aromatic region closely resembled those of 4, except for the replacement of an $A B C D$ system in 4 by an aryl $A B X$ system in 5 . Summarizing its ${ }^{13} \mathrm{C}$ NMR spectra (Figure S35), HSQC (Figure S36), HMBC (Figure S37) and NOESY (Figure S38) correlations proved that the core skeleton of 2-hydroxy-7-methyl-9,10-anthraquinone of 5 was the same as that of 2 . The remaining signals resulting from the 2,2-dimethylpyrano ring moiety at $\delta 1.53\left(6 \mathrm{H}, \mathrm{s}, \mathrm{Me}-4^{\prime} / 5^{\prime}\right), 7.93\left(1 \mathrm{H}, \mathrm{d}, J=10.8 \mathrm{~Hz}, \mathrm{H}-1^{\prime}\right), 5.93(1 \mathrm{H}, \mathrm{d}, J=10.8 \mathrm{~Hz}$, $\left.\mathrm{H}-2^{\prime}\right)$ were also observed. The fusion position of 2,2-dimethylpyrano ring was confirmed at $\mathrm{C}-3(\delta 148.8, \mathrm{~s}) / \mathrm{C}-4(\delta 132.0, \mathrm{~s})$ by the ${ }^{2} J$ - and ${ }^{3} J$-correlations from $\mathrm{H}-1^{\prime}(\delta 7.93)$ to $\mathrm{C}-3$ $(\delta 144.8, \mathrm{~s}) / \mathrm{C}-3^{\prime}(\delta 78.0, \mathrm{~s})$, from $\mathrm{H}-2^{\prime}(\delta 5.93)$ to $\mathrm{C}-3^{\prime}$, and from $\mathrm{Me}-4^{\prime} / \mathrm{Me}-5^{\prime}(\delta 1.53)$ to $C-3^{\prime}$ in the HMBC spectrum of 5 . Consequently, the structure of 5 was elucidated as shown in Figure 1 and named diffusaquinone E.

Compounds 6 and 7 (Figure 1) had the same molecular formula $\mathrm{C}_{20} \mathrm{H}_{16} \mathrm{O}_{5}$, determined according to the HR-ESI-MS analysis (Figures S39 and S40). After careful inspection of the 1D and 2D NMR spectral data (Figures S41-S46), we discovered one significant variation in 6, namely that $\mathrm{H}-2^{\prime}$ in $\mathbf{5}$ had disappeared and instead one hydroxyl group substituted at $\delta 170.0\left(\mathrm{C}-2^{\prime}, \mathrm{s}\right)$ was observed. The location of hydroxy group was determined at $\mathrm{C}-2^{\prime}$ through the HMBC correlations (Figure $\left.\mathrm{S} 46\right)$ of $\mathrm{H}-1^{\prime}(\delta 7.50,1 \mathrm{H}, \mathrm{s})$ to $\mathrm{C}-3(\delta 148.8$, s) $/ \mathrm{C}-2^{\prime}$, and $\mathrm{H}-4^{\prime} / 5^{\prime}(\delta 1.60,6 \mathrm{H}, \mathrm{s})$ to $\mathrm{C}-2^{\prime}$. The ${ }^{13} \mathrm{C}$ NMR data of 6 were assigned as shown in Table 1 based on the HMBC analytical results, and were elucidated as $2^{\prime}$-hydroxy 
diffusaquinone E and named diffusaquinone F. In 1D and 2D NMR (Figures S47-S52) of compound 7, a significant broad singlet at $\delta 12.93$ (brs, $\mathrm{OH}$ ) indicated a hydroxyl group located next to the carbonyl group, leading to the formation of an intramolecular hydrogen bond (Figure S47). Additionally, the aryl ABX system in 6 was replaced by an AB system $(\delta 7.64(1 \mathrm{H}, \mathrm{d}, J=7.6 \mathrm{~Hz}, \mathrm{H}-5)$ and $7.48(1 \mathrm{H}, \mathrm{d}, J=7.6 \mathrm{~Hz}, \mathrm{H}-6))$ in 7 . Its HMBC spectrum (Figure S51) showed correlations from Me-11 $(\delta 7.64, \mathrm{~s})$ to $\mathrm{C}-6(\delta 136.9$, d) $/ \mathrm{C}-7(\delta 133.7, \mathrm{~s}) / \mathrm{C}-8(\delta 160.4, \mathrm{~s})$ and from $\mathrm{H}-1(\delta 7.80, \mathrm{~s})$ to $\mathrm{C}-2(\delta 149.0, \mathrm{~s}) / \mathrm{C}-3$ $(\delta 145.2, \mathrm{~s}) / \mathrm{C}-9(\delta 188.2, \mathrm{~s})$. Combined, these data establish the core skeleton of 7 as 2,8-dihydroxy-7-methyl-9,10-anthraquinone. The remaining proton signals based on a 2,2-dimethylpyrano unit, consisting of two methyls $\left(\delta 1.54\left(6 \mathrm{H}, \mathrm{s}, \mathrm{Me}-4^{\prime} / 5^{\prime}\right)\right)$ and two cis-coupled olefinic protons $\left(\delta 7.92\left(1 \mathrm{H}, \mathrm{d}, J=10.4 \mathrm{~Hz}, \mathrm{H}-1^{\prime}\right)\right.$ and $\delta 5.94(1 \mathrm{H}, \mathrm{d}, J=10.4 \mathrm{~Hz}$, $\left.\mathrm{H}-2^{\prime}\right)$ ), were determined to be fused at $\mathrm{C}-3(\delta 145.2, \mathrm{~s})$ and $\mathrm{C}-4(\delta 122.1, \mathrm{~s})$ by HMBC (Figure S51) and NOESY correlations (Figure S52). This result was further supported by the HMBC correlations, as shown in Figure 2. In conclusion, 7 was characterized as 8-hydroxy diffusaquinone $\mathrm{E}$ and named diffusaquinone $\mathrm{G}$.

\subsection{Anti-Inflammatory Activity}

In addition to the seven anthraquinones discussed above (1-7), thirty-four known constituents were identified, including 2-hydroxy-6-hydroxymethylanthraquinone (8), tectoquinone (9), 2-hydroxymethyl-9,10-anthraquinone (10), 2-formyl-9,10-anthraquinone (11), 2-hydroxy-3-methyl-9,10-anthraquinone (12), 2-methoxy-3-methyl-9,10-anthraquinone (13), digiferruginol (14), 2-hydroxy-3-hydroxymethyl-9,10-anthraquinone (15), 1-methylalizarin (16), 2,6-dihydroxy-3-methyl-9,10-anthraquinone (17), 1-hydroxy-2-methoxy-3-methyl-9,10anthraquinone (18), 2-hydroxy-1-methoxy-3-methyl-9,10-anthraquinone (19), 3-hydroxy2-methoxy-6-methyl-9,10-anthraquinone (20), 2,3-dimethoxy-6-methyl-9,10-anthraquinone (21), 3-hydroxy-2-methoxy-6-hydroxymethyl-9,10-anthraquinone (22), physcion (23), robustaquinone B (24), erythroglaucin (25), capitellataquinone D (26), deacetyl asperulosidic acid methyl ester (27), scandoside methyl ester (28), E-6-O-p-coumaroyl scandoside methyl ester (29), Z-6-O-p-coumaroyl scandoside methyl ester (30), E-6-O-p-methoxycinnamoyl scandoside methyl ester (31), Z-6-O-p-methoxycinnamoyl scandoside methyl ester (32), E-6-O-feruloyl scandoside methyl ester (33), Z-6-O-feruloyl scandoside methyl ester (34), 4,7-dimethoxy-5-methyl-1,3-benzodioxole (35), p-coumaric acid (36), mixture of ursolic acid (37) and oleanolic acid (38), mixture of stigmasterol (39) and $\beta$-sitosterol (40), and aurantiamide acetate (41) (references provided in the Supplementary Data, Appendix A).

Among the isolated constituents, twenty-eight compounds with structural diversity were subjected to the human neutrophil cellular model and examined for their inhibitory activity on superoxide anion generation and elastase release (Table 3). According to the bioactivity data, some anthraquinones exhibited significant anti-inflammatory activity, while other compounds, such as iridoid glycosides (27-34), steroids (39-40), and amide (41), are not active. Compounds 1, 2, and 26, anthraquinones with a 2-isopropyldihydrofuran moiety, displayed the most potent anti-inflammatory activity with the $\mathrm{IC}_{50}$ values ranged from 0.92 to $1.71 \mu \mathrm{M}$ for superoxide anion generation and from 0.71 to $2.40 \mu \mathrm{M}$ for elastase release. Compounds 4 and 5 with a 2,2-dimethylpyrano ring moiety also showed the potent anti-inflammatory activity with the $\mathrm{IC}_{50}$ values of $5.52 \pm 1.59$ and $0.15 \pm 0.01 \mu \mathrm{M}$ for inhibition of superoxide anion generation, and $3.25 \pm 0.80$ and $0.20 \pm 0.02 \mu \mathrm{M}$ for inhibition of elastase release, respectively. However, the substituents of tricyclic 9, 10anthraquinones and their structure-activity relationships are still unclear, and further studies of pharmacological mechanisms and the binding receptor are required. In addition, our unpublished experimental data indicate that the ethanol extract of $H$. diffusa also had a moderate inhibitory effect on hepatitis $C$ virus and Dengue virus. Whether these antiviral effects were related to the anti-inflammatory effects of these compounds remains to be further explored. 
Table 3. Effects of compounds on superoxide anion generation and elastase release in fMLP/CBinduced human neutrophils.

\begin{tabular}{|c|c|c|c|c|c|c|}
\hline \multirow{2}{*}{ Compounds } & \multicolumn{2}{|c|}{ Superoxide Anion } & \multirow{2}{*}{$\begin{array}{c}p \\
\text { Significance }\end{array}$} & \multicolumn{2}{|c|}{ Elastase Release } & \multirow{2}{*}{$\begin{array}{c}p \\
\text { Significance }\end{array}$} \\
\hline & $\mathrm{IC}_{50}(\mu \mathrm{g} / \mathrm{mL})^{\mathrm{b}}$ & Inhibition $\%{ }^{a}$ & & $\mathrm{IC}_{50}(\mu \mathrm{g} / \mathrm{mL})^{\mathrm{b}}$ & Inhibition $\%{ }^{a}$ & \\
\hline 1 & $0.92 \pm 0.22$ & $97.92 \pm 4.14$ & $* * *$ & $0.71 \pm 0.22$ & $111.76 \pm 2.97$ & $* * *$ \\
\hline 2 & $1.71 \pm 0.15$ & $103.01 \pm 0.74$ & $* * *$ & $2.40 \pm 0.36$ & $113.50 \pm 5.04$ & $* * *$ \\
\hline 4 & $5.52 \pm 1.59$ & $61.53 \pm 5.76$ & $* * *$ & $3.25 \pm 0.80$ & $87.18 \pm 2.92$ & $* * *$ \\
\hline 5 & $0.15 \pm 0.01$ & $108.59 \pm 1.66$ & $* * *$ & $0.20 \pm 0.02$ & $112.25 \pm 4.99$ & $* * *$ \\
\hline 8 & $3.55 \pm 0.48$ & $99.28 \pm 0.29$ & $* * *$ & $3.88 \pm 0.48$ & $106.73 \pm 3.10$ & $* * *$ \\
\hline 9 & $1.58 \pm 0.42$ & $80.72 \pm 3.25$ & $* * *$ & $>10$ & $45.45 \pm 6.31$ & $* *$ \\
\hline 11 & $5.29 \pm 0.70$ & $74.47 \pm 2.80$ & $* * *$ & $>10$ & $39.23 \pm 6.61$ & $* *$ \\
\hline 12 & $>10$ & $15.10 \pm 5.84$ & & $>10$ & $31.44 \pm 4.62$ & $* *$ \\
\hline 13 & $>10$ & $27.80 \pm 4.16$ & $* *$ & $>10$ & $30.22 \pm 4.05$ & $* *$ \\
\hline 14 & $>10$ & $45.51 \pm 6.33$ & $* *$ & $>10$ & $29.88 \pm 4.62$ & $* *$ \\
\hline 15 & $2.30 \pm 0.58$ & $97.18 \pm 0.65$ & $* * *$ & $5.12 \pm 0.63$ & $77.38 \pm 2.92$ & $* * *$ \\
\hline 18 & $>10$ & $41.26 \pm 6.15$ & $* * *$ & $>10$ & $18.03 \pm 6.74$ & $*$ \\
\hline 19 & $4.96 \pm 0.30$ & $92.26 \pm 2.51$ & $* * *$ & $5.68 \pm 1.73$ & $67.08 \pm 6.09$ & $* * *$ \\
\hline 20 & $3.66 \pm 0.76$ & $90.28 \pm 6.56$ & $* * *$ & $3.94 \pm 0.77$ & $91.40 \pm 2.14$ & $* * *$ \\
\hline 21 & $>10$ & $43.09 \pm 6.56$ & $* *$ & $>10$ & $13.88 \pm 3.52$ & $*$ \\
\hline 22 & $>10$ & $33.16 \pm 5.19$ & $* * *$ & $>10$ & $40.34 \pm 5.97$ & $* *$ \\
\hline 23 & $>10$ & $14.81 \pm 6.93$ & & $>10$ & $6.63 \pm 1.27$ & $* *$ \\
\hline 25 & $>10$ & $13.25 \pm 5.20$ & * & $>10$ & $8.29 \pm 6.57$ & \\
\hline 26 & $1.46 \pm 0.29$ & $100.83 \pm 0.83$ & $* * *$ & $1.50 \pm 0.25$ & $113.90 \pm 0.69$ & $* * *$ \\
\hline 27 & $>10$ & $2.57 \pm 2.45$ & & $>10$ & $-1.17 \pm 2.02$ & \\
\hline 28 & $>10$ & $13.05 \pm 1.94$ & $* *$ & $>10$ & $9.17 \pm 4.61$ & \\
\hline $29+30$ & $>10$ & $5.56 \pm 0.49$ & $* * *$ & $>10$ & $21.55 \pm 3.17$ & $* *$ \\
\hline $31+32$ & $>10$ & $8.07 \pm 3.06$ & & $>10$ & $10.23 \pm 2.80$ & * \\
\hline $33+34$ & $>10$ & $14.71 \pm 2.44$ & $* *$ & $>10$ & $-1.47 \pm 2.84$ & \\
\hline 35 & $0.90 \pm 0.23$ & $80.63 \pm 1.22$ & $* * *$ & $5.15 \pm 1.10$ & $70.08 \pm 2.36$ & $* * *$ \\
\hline $37+38$ & $0.41 \pm 0.05$ & $105.16 \pm 1.41$ & $* * *$ & $1.81 \pm 0.66$ & $96.90 \pm 5.09$ & $* * *$ \\
\hline $39+40$ & $>10$ & $4.90 \pm 4.15$ & & $>10$ & $2.68 \pm 3.00$ & \\
\hline 41 & $>10$ & $16.75 \pm 4.02$ & * & $>10$ & $21.21 \pm 4.22$ & $* *$ \\
\hline LY294002 & $0.75 \pm 0.18$ & $96.91 \pm 5.99$ & $* * *$ & $1.26 \pm 0.48$ & $88.81 \pm 1.59$ & $* * *$ \\
\hline
\end{tabular}

a Percentage of inhibition (Inh.\%) at $10 \mu \mathrm{g} / \mathrm{mL}$ concentration. Results are presented as mean \pm S.E.M. $(n=3-4)$ ${ }^{*} p<0.05,{ }^{* *} p<0.01,{ }^{* * *} p<0.001$ compared with the control value. ${ }^{\mathrm{b}}$ Concentration necessary for $50 \%$ inhibition $\left(\mathrm{IC} \mathrm{C}_{50}\right)$.

\subsection{Molecular Docking Study}

Molecular docking is a popular computing technique that can accurately predict the conformation and affinity between the ligand and the active pocket [33,34]. The docking method provides the high-dimensional space for possible interactions and evaluates the ranking of candidates based on a scoring function [35]. To illustrate the binding ability between anthraquinones and human neutrophil elastase, compounds 1, 5, and GW475151 were selected for molecular docking studies based on the above-mentioned experimental results. The binding affinity is shown in $\mathrm{kcal} / \mathrm{mol}$ according to the computing results, and the calculated complex with the lowest energy was designed as the best docking configuration. GW475151 is an elastase inhibitor and is used as a native binding ligand [36]. It binds to elastase via Gly219 by hydrogen bond, and other amino acid residues Val216 and Cys191 by alkyl and amide- $\pi$-stacked interactions, and van der Waals (Figure 3). A stable complex is formed with binding energy of $-6.0 \mathrm{kcal} / \mathrm{mol}$ (Table 4). Compounds $\mathbf{1}$ and $\mathbf{5}$ display even lower binding energy, and it indicates that they connect to proteins easier than GW475151 (Table 4). Several interactions are completed between 1 and elastase, including hydrogen bonds between Val216 and A-ring and carbonyl group of 1; moreover, other interactions $\pi$-sigma, $\pi$ - $\pi$ T-shaped, alkyl, $\pi$-alkyl are linked to elastase by Leu99B, His57, Arg217A, and Phe215. 5 is bound with His57, Va199, and Val216 through hydrogen bond and linked with Phe215, Leu99B, Arg217A, and Phe192 via $\pi$-sigma, $\pi$ - $\pi$ T-shaped, alkyl, and $\pi$-alkyl effects, respectively. These interactions promote 5 and elastase to establish a stable unit, therefore resulting in a significant binding affinity with the receptor. All these 
computing results coincide well with the experimental data of the bioactivity examination. Therefore, it is speculated that the inhibition of elastase release may be related to the binding of anthraquinones with elastase, and further pharmacological mechanisms need to be verified.

A

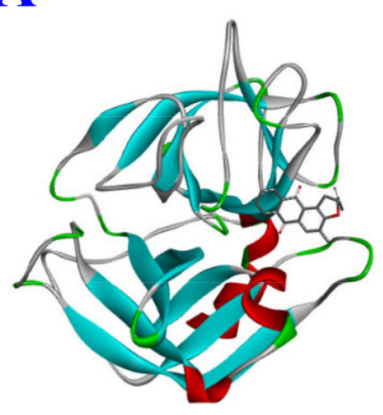

B

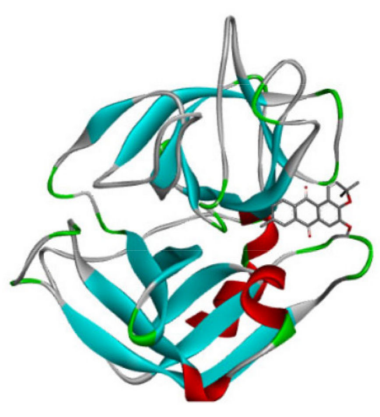

C

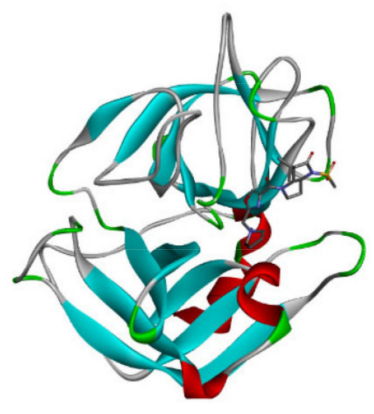

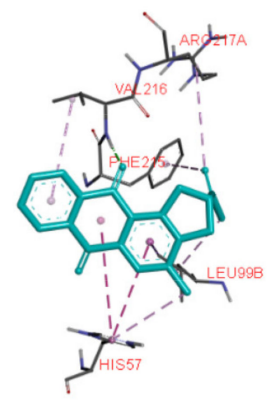

A: $\begin{gathered}\text { ARG } \\ \text { A:217A }\end{gathered}$

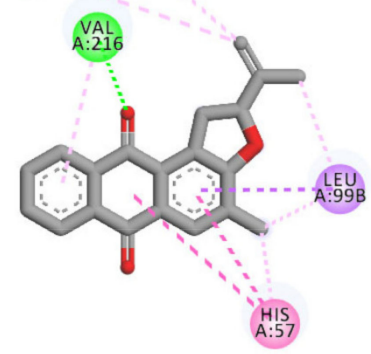

Interactions
Conventional Hydrogen Bond
Pi-Sigma

Pi.Pi T-shaped

$\square$ Alkyl

$\square$ Pi-Alkyl

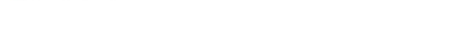

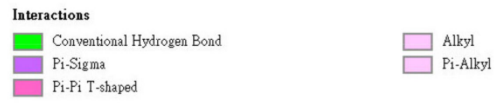

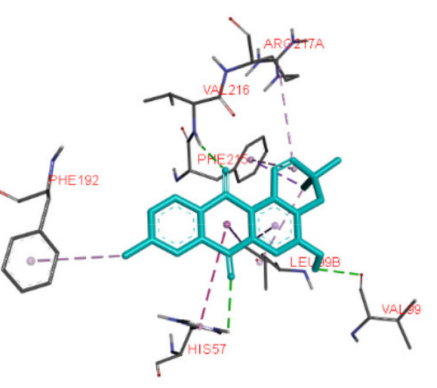

PHE ARG A A:116

PHE

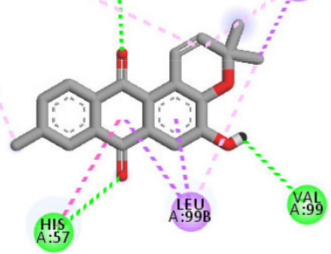

A.

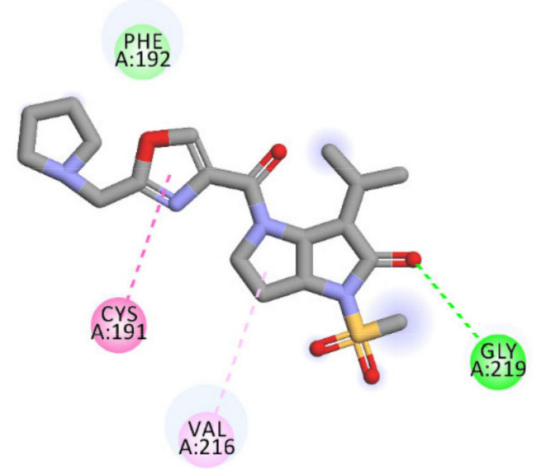

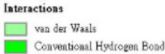

Figure 3. In silico modeling of (A) 1, (B) 5, and (C) GW475151 docking into the human neutrophil elastase receptor. 
Table 4. In silico computing binding energies of compounds 1, 5, and GW475151.

\begin{tabular}{cc}
\hline Ligands & Binding Affinity (kcal/mol) \\
\hline $\mathbf{1}$ & -6.9 \\
$\mathbf{5}$ & -7.2 \\
GW475151 & -5.8 \\
\hline
\end{tabular}

\section{Conclusions}

In summary, a total of forty-one compounds, including seven new anthraquinones, were isolated from EtOAc layer of the ethanolic extract of Hedyotis diffusa. Among all the isolated compounds, anthraquinones and iridoids glycosides were the main components. Some anthraquinones, especially with 2-isopropyldihydrofuran or 2,2-dimethylpyrano moiety, showed promising anti-inflammatory activities for inhibiting superoxide anion generation and elastase release. Compound $\mathbf{1}$ with a 2-isopropyldihydrofuran moiety displayed the most potent anti-inflammatory activity for superoxide anion generation and elastase release with $\mathrm{IC}_{50}$ values $0.92 \pm 0.22 \mu \mathrm{M}$ and $0.71 \pm 0.22 \mu \mathrm{M}$, respectively. Compound 5 containing the 2,2-dimethylpyrano ring moiety inhibited superoxide anions generation and elastase release with the $\mathrm{IC}_{50}$ values of $0.15 \pm 0.01 \mu \mathrm{M}$ and $0.20 \pm 0.02 \mu \mathrm{M}$, respectively. These additional functional groups can significantly improve the anti-inflammatory effects of anthraquinones. The calculation results of molecular docking also confirmed the good binding affinity of $\mathbf{1}$ and $\mathbf{5}$ with neutrophil elastase. These functional groups are usually observed in natural products such as coumarins, acridones, and flavonoids but are rarely found in the anthraquinone skeleton. Such substructures can be used as a reference for medicinal chemistry derivation of anti-inflammatory lead compounds and as new candidates for the adjuvant therapy in the future.

Supplementary Materials: The following supporting information can be downloaded at https: / / www.mdpi.com/article/10.3390/antiox11020335/s1: Figures S1-S52: NMR and HRMS spectra of new compounds $1-7$.

Author Contributions: Conceptualization, T.-S.W.; methodology, P.-C.K. and T.-L.H.; investigation, H.-Y.H., and I.-T.C.; resources, K.-C.C.; data curation, Y.-C.L. and S.-H.L.; writing-original draft preparation, P.-C.K. and S.-H.L.; writing-review and editing, T.-S.W. All authors have read and agreed to the published version of the manuscript.

Funding: This research was funded by the Ministry of Science and Technology, Taiwan (MOST), awarded to S.-H.L. and T.-S.W. The research was supported in part by High Education Sprout Project, Ministry of Education to the Headquarters of University Advancement at National Cheng Kung University (NCKU).

Institutional Review Board Statement: The study was conducted with the approval of the Institutional Review Board of Chang Gung Memorial Hospital (IRB No. 103-7405A3).

Informed Consent Statement: Informed consent was obtained from all subjects involved in the study.

Data Availability Statement: Data is contained within the article.

Acknowledgments: Thanks to Ju-Chien Cheng, Department of Medical Laboratory Science and Biotechnology, China Medical University for assisting in the hepatitis C virus assay. Authors are also thankful to Hsiao-Ching Yu, the High Valued Instrument Center, National Sun Yat-Sen University, for the mass (MS000600) spectra. The authors gratefully acknowledge the use of NMR0050000 and NMR005700 equipment belonging to the Core Facility Center of National Cheng Kung University.

Conflicts of Interest: The authors declare no conflict of interest.

\section{Appendix A}

References for Known Compounds 2-hydroxy-6-hydroxymethylanthraquinone (8), ${ }^{1}$ tectoquinone (9), ${ }^{2}$ 
2-hydroxymethyl-9,10-anthraquinone (10), ${ }^{3}$

2-formyl-9,10-anthraquinone (11), 4

2-hydroxy-3-methyl-9,10-anthraquinone (12), 5

2-methoxy-3-methyl-9,10-anthraquinone (13), 6

digiferruginol (14), 7

2-hydroxy-3-hydroxymethyl-9,10-anthraquinone (15), 8

1-methylalizarin (16), 8

2,6-dihydroxy-3-methyl-9,10-anthraquinone (17), ${ }^{9}$

1-hydroxy-2-methoxy-3-methyl-9,10-anthraquinone (18), 10

2-hydroxy-1-methoxy-3-methyl-9,10-anthraquinone (19), 5

3-hydroxy-2-methoxy-6-methyl-9,10-anthraquinone (20), 11

2,3-dimethoxy-6-methyl-9,10-anthraquinone (21), 12

3-hydroxy-2-methoxy-6-hydroxymethyl-9,10-anthraquinone (22), 13

physcion (23), 14

robustaquinone B (24), 15

erythroglaucin (25), 16

capitellataquinone D (26), 17

deacetyl asperulosidic acid methyl ester (27), 18

scandoside methyl ester (28), 18

E-6-O-p-coumaroyl scandoside methyl ester (29), 19

Z-6-O-p-coumaroyl scandoside methyl ester (30), 19

E-6-O-p-methoxycinnamoyl scandoside methyl ester (31), 19

Z-6-O-p-methoxycinnamoyl scandoside methyl ester (32), 19

E-6-O-feruloyl scandoside methyl ester (33), 19

Z-6-O-feruloyl scandoside methyl ester (34), 19

4,7-dimethoxy-5-methyl-1,3-benzodioxole (35), 20

$p$-coumaric acid (36), 21

mixture of ursolic acid (37) and oleanolic acid (38), 22

mixture of stigmasterol (39) and $\beta$-sitosterol (40), ${ }^{23}$

aurantiamide acetate (41), 24

\section{References}

1. Flora of Taiwan, 2nd ed.; Editorial Committee of the Flora of Taiwan: Taipei, Taiwan, 1998; Volume 4, p. 267.

2. Medicinal Plant Images Database, Hong Kong Baptist University. Available online: https://libproject.hkbu.edu.hk/was40/ detail?channelid=1288\&searchword=herb_id=D01227 (accessed on 21 September 2021).

3. Chen, R.; He, J.; Tong, X.; Tang, L.; Liu, M. The Hedyotis diffusa Willd. (Rubiaceae): A Review on Phytochemistry, Pharmacology, Quality Control and Pharmacokinetics. Molecules 2016, 21, 710. [CrossRef]

4. Wang, C.; Xin, P.; Wang, Y.; Zhou, X.; Wei, D.; Deng, C.; Sun, S. Iridoids and sfingolipids from Hedyotis diffusa. Fitoterapia 2018, 124, 152-159. [CrossRef]

5. Huang, W.H.; Yu, S.H.; Li, Y.B.; Jiang, J.Q. Four anthraquinones from Hedyotis diffusa. J. Asian Nat. Prod. Res. 2008, 10, 887-889. [CrossRef]

6. Li, C.; Zhao, Y.; Guo, Z.; Zhang, X.; Xue, X.; Liang, X. Effective 2D-RPLC/RPLC enrichment and separation of micro-components from Hedyotis diffusa Willd. and characterization by using ultra-performance liquid chromatography/quadrupole time-of-flight mass spectrometry. J. Pharm. Biomed. Anal. 2014, 99, 35-44. [CrossRef]

7. Huang, W.; Li, Y.; Jiang, J. Chemical constituents from Hedyotis diffusa. Zhongguo Zhong Yao Za Zhi 2009, 34, 712-724.

8. Yan, C.; Kong, F.; Ou, X. Antioxidant and anti-glycated activities of polysaccharides in vitro isolated from Hedyotis diffusa Wild. J. Med. Plant Res. 2012, 6, 2895-2900.

9. Lin, C.C.; Ng, L.T.; Yang, J.J.; Hsu, Y.F. Anti-inflammatory and hepatoprotective activity of Peh-Hue-Juwa-Chi-Cao in male rats. Am. J. Chin. Med. 2002, 30, 225-234. [CrossRef]

10. Shi, Y.; Wang, C.H.; Gong, X.G. Apoptosis-inducing effects of two anthraquinones from Hedyotis diffusa WILLD. Biol. Pharm. Bull. 2008, 31, 1075-1078. [CrossRef]

11. Lin, J.; Wei, L.; Shen, A.; Cai, Q.; Xu, W.; Li, H.; Zhan, Y.; Hong, Z.; Peng, J. Hedyotis diffusa Willd extract suppresses Sonic hedgehog signaling leading to the inhibition of colorectal cancer angiogenesis. Int. J. Oncol. 2013, 42, 651-656. [CrossRef]

12. Wei, L.; Lin, J.; Xu, W.; Cai, Q.; Shen, A.; Hong, Z.; Peng, J. Scutellaria barbata D. Don inhibits tumor angiogenesis via suppression of Hedgehog pathway in a mouse model of colorectal cancer. Int. J. Mol. Sci. 2012, 13, 9419-9430. [CrossRef] 
13. Cai, Q.; Lin, J.; Wei, L.; Zhang, L.; Wang, L.; Zhan, Y.; Zeng, J.; Xu, W.; Shen, A.; Hong, Z.; et al. Hedyotis diffusa Willd inhibits colorectal cancer growth in vivo via inhibition of STAT3 signaling pathway. Int. J. Mol. Sci. 2012, 13, 6117-6128. [CrossRef]

14. Lin, C.C.; Kuo, C.L.; Lee, M.H.; Hsu, S.C.; Huang, A.C.; Tang, N.Y.; Lin, J.P.; Yang, J.S.; Lu, C.C.; Chiang, J.H.; et al. Extract of Hedyotis diffusa Willd influences murine leukemia WEHI-3 cells in vivo as well as promoting T- and B-cell proliferation in leukemic mice. In Vivo 2011, 25, 633-640.

15. Hu, E.; Wang, D.G.; Chen, J.Y.; Tao, X.L. Novel cyclotides from Hedyotis diffusa induce apoptosis and inhibit proliferation and migration of prostate cancer cells. Int. J. Clin. Exp. Med. 2015, 8, 4059-4065.

16. Yang, X.Z.; Hao, Z.Y.; Zhu, Y.C.; Dong, Y. Effects of different solvents and extraction methods on antioxidant activity of Hedyotis diffusa Extract. Guizhou Agric. Sci. 2014, 42, 43-45.

17. Lee, H.Z.; Bau, D.T.; Kuo, C.L.; Tsai, R.Y.; Chen, C.Y.; Chang, Y.H. Clarification of the phenotypic characteristics and anti-tumor activity of Hedyotis diffusa. Am. J. Chin. Med. 2011, 39, 201-213. [CrossRef]

18. Wang, J.H.; Shu, L.H.; Yang, L.L.; Zhang, M.; He, P. 2-Hydroxy-3-methylanthraquinone from Hedyotis diffusa Willd. Induces apotosis via alteration of Fas/FasL and activation of caspase-8 in human leukemic THP-1 cells. Arch. Med. Res. 2011, 42, 577-583. [CrossRef]

19. Liu, Z.; Liu, M.; Liu, M.; Li, J.C. Methylanthraquinone from Hedyotis diffusa Willd. Induces Ca ${ }^{2+}$-medicated apoptosis in human breast cancer cells. Toxicol. In Vitro 2010, 24, 142-147. [CrossRef]

20. Wang, N.; Li, D.Y.; Niu, H.Y.; Zhang, Y.; He, P.; Wang, J.H. 2-Hydroxy-3-methylanthraquinone from Hedyotis diffusa Willd induces apoptosis in human leukemic U937 cells through modulation of MAPK pathways. Arch. Pharm. Res. 2013, 36, 752-758. [CrossRef]

21. Xu, G.H.; Kim, Y.H.; Chi, S.W.; Choo, S.J.; Ryoo, I.J.; Ahn, J.S.; Yoo, I.D. Evaluation of human neutrophil elastase inhibitory effect of iridoid glycosides from Hedyotis diffusa. Bioorg. Med. Chem. Lett. 2010, 20, 513-515. [CrossRef]

22. Luo, S.Y.; Zhong, Z.G.; Zhou, L. Experimental study of the total flavonoids of Oldenlandia diffusa on ulcerative colitis in the rats Chin. J. Hosp. Pharm. 2011, 31, 437-440.

23. Lin, L.; Cheng, K.; Xie, Z.; Chen, C.; Chen, L.; Huang, Y.; Liang, Z. Purification and characterization a polysaccharide from Hedyotis diffusa and its apoptosis inducing activity toward human lung cancer cell line A549. Int. J. Biol. Macromol. 2019, 122, 64-71. [CrossRef]

24. Coussens, L.M.; Werb, Z. Inflammation and cancer. Nature 2002, 420, 860-867. [CrossRef]

25. Malech, H.L.; Gallin, J.I. Current concepts: Immunology. Neutrophils in human diseases. N. Engl. J. Med. 1987, 317, 687-694. [CrossRef]

26. Van Eeden, S.F.; Klut, M.E.; Walker, B.A.M.; Hogg, J.C. The use of flow cytometry to measure neutrophil function. J. Immunol. Methods 1999, 232, 23-43. [CrossRef]

27. Yang, S.C.; Chung, P.J.; Ho, C.M.; Kuo, C.Y.; Hung, M.F.; Huang, Y.T.; Chang, W.Y.; Chang, Y.W.; Chan, K.H.; Hwang, T.L. Propofol Inhibits Superoxide Production, Elastase Release, and Chemotaxis in Formyl Peptide-Activated Human Neutrophils by Blocking Formyl Peptide Receptor 1. J. Immunol. 2013, 190, 6511-6519. [CrossRef]

28. Kuo, P.C.; Tai, S.H.; Hung, C.C.; Hwang, T.L.; Kuo, L.M.; Lam, S.H.; Cheng, K.C.; Kuo, D.H.; Hung, H.Y.; Wu, T.S. Antiinflammatory triterpenoids from the fruiting bodies of Fomitopsis pinicola. Bioorg. Chem. 2021, 108, 104562. [CrossRef]

29. Trott, O.; Olson, A.J. AutoDock Vina: Improving the speed and accuracy of docking with a new scoring function, efficient optimization, and multithreading. J. Comput. Chem. 2010, 31, 455-461. [CrossRef]

30. BIOVIA; Dassault Systèmes. Discovery Studio Client 2020, v.20.1.0.19295; Dassault Systèmes: San Diego, CA, USA, 2019.

31. Thomson, R.H. Naturally Occuring Quinones, 2nd ed.; Academic Press: London, UK; New York, NY, USA, 1971.

32. Ishii, H.; Sekiguchi, F.; Ishikawa, T. Studies on the chemical constituents of Rutaceous plants-XLI: Absolute configuration of rutaretin methyl ether. Tetrahedron 1981, 37, 285-290. [CrossRef]

33. Brooijmans, N.; Kuntz, I.D. Molecular recognition and docking algorithms. Annu. Rev. Biophys. Biomol. Struct. 2003, 32, 335-373. [CrossRef]

34. Muegge, I.; Rarey, M. Small molecule docking and scoring. In Reviews in Computational Chemistry; Lipkowitz, K.B., Boyd, D.B., Eds.; Wiley: Hoboken, NJ, USA, 2001; Volume 17, pp. 1-60.

35. Halperin, I.; Ma, B.; Wolfson, H.; Nussinov, R. Principles of docking: An overview of search algorithms and a guide to scoring functions. Proteins 2002, 47, 409-443. [CrossRef]

36. Macdonald, S.J.; Dowle, M.D.; Harrison, L.A.; Clarke, G.D.; Inglis, G.G.; Johnson, M.R.; Shah, P.; Smith, R.A.; Amour, A.; Fleetwood, G.; et al. Discovery of further pyrrolidine trans-lactams as inhibitors of human neutrophil elastase (HNE) with potential as development candidates and the crystal structure of HNE complexed with an inhibitor (GW475151). J. Med. Chem. 2002, 45, 3878-3890. [CrossRef] 